\title{
Determinants of downside risk exposure of dairy farms
}

\section{Journal Article}

Author(s):

Finger, Robert (1D; Dalhaus, Tobias (D); Allendorf, Joseph; Hirsch, Stefan

Publication date:

2018-09

Permanent link:

https://doi.org/10.3929/ethz-b-000266730

\section{Rights / license:}

Creative Commons Attribution 4.0 International

\section{Originally published in:}

European Review of Agricultural Economics 45(4), https://doi.org/10.1093/erae/jby012 


\section{Postprint}

This is the accepted version of a paper published in the European Review of Agricultural Economics. This paper has been peer-reviewed but does not include the final publisher proof-corrections or journal pagination.

\section{Citation for the original published paper:}

Finger, R., Dalhaus, T., Allendorf, J., Hirsch, S. (2018). Determinants of downside risk exposure of dairy farms. European Review of Agricultural Economics 45(4), 641-674

Access to the published version may require subscription.

N.B. When citing this work, cite the original published paper. 


\title{
Determinants of downside risk exposure of dairy farms
}

\section{Robert Finger, Tobias Dalhaus, Joseph Allendorf, Stefan Hirsch}

\begin{abstract}
We investigate determinants of dairy producers' risk exposure using a unique combination of foci on i) downside risks, ii) a holistic representation of revenues from milk and animal sales, iii) climatic extremes and iv) the role of animal health. A sample of German dairy farms reveals that animal health and heat stress indicators influence mean and semi-variance of revenues. For instance, heat stress exposure reduces expected milk revenues significantly. In the case of animal health related indicators, our results show trade-offs between expected revenues and downside risks. Furthermore, variabilities in revenues from milk and animal sales are significantly interrelated.
\end{abstract}

Keywords: production risk, animal health, climate extremes, stochastic multi-output production, dairy sector

JEL codes: Q12, Q14, D81

\section{Introduction}

The dairy sector is vitally important for agriculture, especially in Europe which is the largest milk producer worldwide (e.g., Bouamra-Mechemache et al., 2008, Hirsch and Hartmann, 2014). Dairy producers face a number of risks, such as volatile quantities and qualities of outputs, institutional risks and fluctuating market prices (e.g., Chen et al., 2006, D’Antoni and Mishra, 2012, Henry et al., 2016, Valvekar et al., 2011, Wolf et al., 2009). Production risks have been identified as crucial (Berentsen et al., 2012, Chen et al., 2006, El Benni and Finger, 2013, Orea and Wall 2012, Tveteras et al., 2011) and are assumed to be driven by two main factors. Firstly, climatic variability and extreme climatic events affect the quantity and quality of animal products, such as milk and meat (e.g., Kadzere et al., 2002, Key and Sneeringer 2014, Tubiello et al., 2007). Secondly, animal health is essential for the production process and represents an important managerial component and source of income variability (e.g., Allendorf and Wettemann 2015, Antle and Goodger 1984, Lusk and Norwood 2011, Hansson and Lagerkvist, 2014). Animal health can comprise various dimensions and is reflected in animal health related indicators such as metabolic stress, the number of mastitis cases per cow or the frequency of animal losses (Oltenacu and Broom 2010) ${ }^{1}$. Moreover, dairy production is characterized by a joint realization of sales of milk and animals. In addition, revenues from animal sales are stochastic and contribute to adjustments of overall risks faced by the farm (e.g., Tveteras et al., 2011). The identification of key risk determinants in dairy production and the quantification of their impacts, combined with a deeper understanding of farm-level responses to risks are of outmost importance when seeking to support farmers' risk management strategies, develop improved risk management tools and better policies.

We aim to identify determinants of downside risk exposure in dairy farms and quantify their effects. We provide the first analysis of risks in dairy production that covers a unique combination of foci on i) downside risks, ii) a holistic representation of revenues from milk and animal sales, iii) climatic extremes and iv) the role of animal health. This extends earlier research on risks in dairy production that has focused only on individual aspects (e.g., Tveteras et al., 2011, Antle and Goodger 1984, Key and Sneeringer 2014). Our analysis tests the significance of different determinants of production risks in the dairy sector, quantifies marginal effects of various inputs on farm-level revenues and revenues variability and thus aids

\footnotetext{
${ }^{1}$ More generally, Curtis (2007) proposes a performance-oriented perspective on the animal state of being, e.g., by addressing a gap between the potential and the observed production and reproductive performance.
} 
the development of better policies to overcome risks. Furthermore, we extend the current literature by identifying non-linearities and critical thresholds for risk exposure of dairy farms.

To this end, we develop a multi-output stochastic production framework that is applied to a case study on dairy production in Germany, the largest European milk producer and processor. We use a rich panel dataset of 390 dairy farms over the time span from 2007 to 2014 that includes details on the economic performance of the farms, animal health indicators as well as production relevant indicators for weather extremes. Our econometric model accounts for the effects of various inputs and control variables on mean and semi-variance of revenues from milk and animal sales. Moreover, the joint production framework chosen in our analysis allows us to consider input and control variable effects on the semi-covariance between both outputs.

The remainder of this paper is structured as follows. We start by developing the theoretical economic and econometric backgrounds. The econometric implementation and the dataset used are described in the next section. Subsequently, results are presented and discussed. The final section contains our concluding remarks.

\section{$2 \quad$ Economic and econometric framework}

\subsection{Economic framework}

We use a stochastic production function framework to describe effects of different inputs on expected outputs as well as production risks (see Saastamoinen 2015, for a recent survey). In line with Antle (1983), we assume that farmers maximize their utility with respect to a vector of inputs $\mathbf{X}$ taking into account moments $(1, \ldots, m)$ of different outputs produced $(1, \ldots, j)$ as follows:

$$
\max _{x} E[U(\pi)]=h\left[\mu_{1}^{1}(\mathbf{X}), \mu_{2}^{1}(\mathbf{X}), \ldots, \mu_{m}^{1}(\mathbf{X}) ; \ldots ; \mu_{1}^{j}(\mathbf{X}), \mu_{2}^{j}(\mathbf{X}), \ldots, \mu_{m}^{j}(\mathbf{X})\right]
$$

where $\mu_{1}^{j}(\mathbf{X})$ represents the expected revenues of output $j$, and $\mu_{k}=E\left(\Pi^{j}-\mu_{1}^{j}\right)^{k}, k=2, \ldots, m$ denotes the $m$-th moment of the distribution with $\Pi^{j}$ being the vector of realizations of revenues for output $j$.

The analysis of risk in dairy production is often restricted to the variance of revenues (see Antle and Goodger 1984, for an exception). The focus of this assumption is only valid if mean and variance are sufficient to describe the revenue distribution, i.e., no higher moments exist, and/or farmers have no preferences for higher moments. However, these assumptions are rarely fulfilled as agricultural returns are characterized by extreme loss events and farmers are often downside risk averse (e.g., Antle 1983, Di Falco and Chavas 2006, Koundouri et al., 2009). In fact, downside risk exposure can create liquidity problems for a dairy farm and potentially lead to bankruptcy (Hansson and Lagerkvist, 2014). Expanding the framework to higher moments such as skewness and kurtosis often faces an empirical challenge, namely that null hypotheses are not rejected (e.g., Kim et al., 2014)².

Therefore, we propose the use of a semi-variance approach (see also Miranda and Glauber 1991, Vedenov and Barnett 2004) to account for downside risk without expanding the number of equations to be estimated. Semi-variance only accounts for losses that are below a specific benchmark. Here we focus on revenue realizations below the expected value so that the semi-variance of output $j$ can be defined as $\operatorname{SVar}_{j}(\mathbf{X})=E\left\{\Pi^{j}(\mathbf{X})-E\left(\Pi^{j}(\mathbf{X})\right)\right\}^{2} \forall \Pi^{j}(\mathbf{X})<E\left(\Pi^{j}(\mathbf{X})\right)$. This semi-variance equals the variance for symmetric distributions. In contrast, if the revenue distribution is skewed, semi-variance and variance differ (Estrada 2004). If the distribution of revenues is negatively skewed, representing downside risks, the semi-variance is larger than the variance. Thus, the expected utility approximated with semi-variances

\footnotetext{
${ }^{2}$ Similarly, in our analysis, the consideration of skewness and co-skewness did not reveal any conclusive empirical findings.
} 
is lower than for an approximation with variances. The focus on semi-variance thus allows the downside

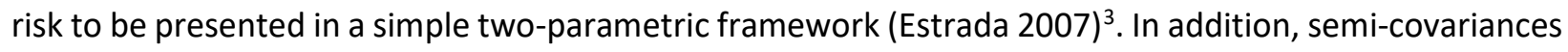
represent the interrelation of downside risk exposure across different outputs. More specifically, we consider two outputs of dairy farms: milk and animal sales.

Focus is usually placed on the variability of production quantities (e.g., Antle and Goodger 1984). Our approach, with concentration on revenues, is an improvement on this for the following reasons. Firstly, revenue accounts for the variability of both quantity and quality of production, as the quality is implicitly considered in output prices. Secondly, as animals are sold at various stages, i.e., ranging from calves and heifers through to dairy cows sold off when they no longer serve for milk production, a quantity- based comparison (e.g., based on kg or number of animals sold) is not meaningful. Thirdly, revenues also implicitly include price variabilities. Thus, revenues also account for correlations between quantities and prices for both outputs, i.e., for the effects of natural hedge (e.g., Schmit et al., 2001). Fourthly, revenues reflect farmers' goal functions better than production quantities. Hence, revenue variabilities allow an unbiased assessment of risks faced by farmers (e.g., El Benni et al., 2016). Furthermore, as input costs are expected to be deterministic, we assume that the focus on the distribution of revenues suffices to infer on the variability of income. Finally, investigating the determinants of downside risk for milk and animal sales separately has two important advantages over an analysis using aggregated revenues. It allows us to identify potentially asymmetric effects of management variables and climatic shocks on different sources of income. Moreover, by exposing the interrelation between two major income sources, we are able to identify potential drivers of high risk events, where losses in both outputs occur jointly. This provides a better overall view of farm-level risks and helps to identify farm-level mechanisms of risk management behavior.

Thus, our framework focusses on mean, semi-variance and semi-covariance of revenues from milk and animal sales ( $j=1$ and 2, respectively), so that Equation 1 simplifies to

$\max _{x} E[U(\pi)]=h\left[E\left(\Pi^{1}(\mathbf{X})\right), S \operatorname{Var}\left(\Pi^{1}(\mathbf{X})\right) ; E\left(\Pi^{2}(\mathbf{X})\right), \operatorname{SVar}\left(\Pi^{2}(\mathbf{X})\right)\right]$. In our analysis, an input $x_{l}$ can decrease or increase the semi-variance, i.e., can be downside risk de- or increasing, or can have no effect on revenue semi-variance: $\frac{\partial S V a r_{j}}{\partial x_{l}}<=>0$.

Since milk production and animal sales are by nature closely linked, we assume inputs to be non-allocable (see also Tveteras et al., 2011). Thus, input use not only influences the distribution of individual revenues, but also the semi-covariance of revenues. With $s_{1}$ and $s_{2}$ representing the shares of milk and animal sales in total sales, mean and semi-variance of total revenues $\pi$ arising from milk and sales of animals can be summarized as follows:

$$
E(\pi)=s_{1} E\left(\Pi^{1}(\mathbf{X})\right)+s_{2} E\left(\Pi^{2}(\mathbf{X})\right)
$$

for expected total revenues and

$$
\operatorname{SVar}(\pi)=s_{1}^{2} \operatorname{SVar}\left(\Pi^{1}(\mathbf{X})\right)+s_{2}^{2} \operatorname{SVar}\left(\Pi^{2}(\mathbf{X})\right)+2 s_{1} s_{2} \operatorname{SCov}_{1,2}(\mathbf{X})
$$

for total semi-variance (e.g., Estrada 2007).

Note that we assume a (downside) risk averse farmer, so that the utility increases for higher levels of expected revenues $E(\pi)$, but decreases for, ceteris paribus, higher levels of revenue semi-variance $\operatorname{SVar}(\pi) . \operatorname{SCov}_{1,2}(\mathbf{X})$ is the semi-covariance between revenues from both outputs, defined as $S \operatorname{Cov}_{1,2}(\mathbf{X})=E\left[\left\{\Pi^{1}(\mathbf{X})-E\left(\Pi^{1}(\mathbf{X})\right)\right\} \cdot\left\{\Pi^{2}(\mathbf{X})-E\left(\Pi^{2}(\mathbf{X})\right)\right\}\right] \forall \Pi^{j}(\mathbf{X})<E\left(\Pi^{j}(\mathbf{X})\right) . \quad$ If $\quad$ revenue realizations below the expected revenue levels are not perfectly positively correlated, the overall risk is reduced due to diversification to two assets instead of one. Thus, a decrease in the semi-covariance

\footnotetext{
${ }^{3}$ In general, the focus on lower partial moments as risk measure is consistent with maximization of expected utility (Gatzert
} and Kling 2007, Jarrow and Zhao 2006) and provides a more coherent representation of downside risks (e.g., Antle 2010). 
indicates, ceteris paribus, a decrease in the overall risk faced by the farmer and thus a utility increase. We estimate marginal effects of inputs on mean and semi-variance of both outputs as well as on their semicovariance.

\subsection{Econometric framework}

A stochastic production function according to Just and Pope (1978) and Antle (1983) is used to estimate the effects of inputs and other factors on the mean, semi-variance and semi-covariance of revenue distribution. The relationships between inputs and expected revenues from the two outputs milk and animal sales are estimated as follows:

$$
\begin{aligned}
& \Pi^{1}=f_{1}(\mathbf{X})+e_{1} \\
& \Pi^{2}=f_{2}(\mathbf{X})+e_{2}
\end{aligned}
$$

where $f_{1}$ and $f_{2}$ are production functions to be estimated and represent $\mu_{1}^{1}(\mathbf{X})$ and $\mu_{1}^{2}(\mathbf{X})$, while $e_{1}$ and $e_{2}$ are error terms, which contain information on the riskiness of production and the effects of inputs on semi-variances and semi-covariance. We assume that $E\left(e_{1}\right)=0, E\left(e_{2}\right)=0$ as well as $E\left[\left(e_{1}^{-}\right)^{2}\right]=$ $\operatorname{SVar}\left(\Pi^{1}(\mathbf{X})\right)$ and $E\left[\left(e_{2}^{-}\right)^{2}\right]=\operatorname{SVar}\left(\Pi^{2}(\mathbf{X})\right)$, where $e_{i}^{-}$represents negative outcomes of $e_{i}$, i.e., realizations below expected levels.

The effect of inputs on revenue semi-variances is estimated as follows:

$$
\begin{aligned}
& E\left[\left(e_{1}^{-}\right)^{2}\right]=g_{1}(\mathbf{X})+\varepsilon_{1} \\
& E\left[\left(e_{2}^{-}\right)^{2}\right]=g_{2}(\mathbf{X})+\varepsilon_{2}
\end{aligned}
$$

where $g_{1}$ and $g_{2}$ are semi-variance functions to be estimated that indicate the effects of inputs and other factors on semi-variances.

Moreover, the semi-covariance between production of both outputs is empirically captured by $\operatorname{SCov}\left(e_{1}^{-}, e_{2}^{-}\right)$, which is used to estimate the effects of input use via the covariance function $g_{3}$ :

$$
\operatorname{SCov}\left(e_{1}^{-}, e_{2}^{-}\right)=E\left[e_{1}^{-} \cdot e_{2}^{-}\right]=g_{3}(\mathbf{X})+\varepsilon_{3}
$$

\subsection{Econometric implementation}

The production function forms most commonly used, such as the Cobb-Douglas, other CES functions, or transcendental, are subject to major limitations regarding the representation of production technologies (e.g., Driscoll et al., 1992; Asche and Tveteras 1999). Moreover, these production functions restrict marginal risk to the positive state and therefore do not allow for risk reducing input factors (Wan and Anderson 1990). Therefore, more flexible functional forms, such as linear quadratic (LQ), Generalized Leontief, or translog are needed for the empirical estimation of the mean function. We follow Asche and Tveteras (1999) and employ a linear quadratic (LQ) functional form ${ }^{4}$ for the mean revenue function of output $j$ that also controls for animal health, climatic variability, and milk quotas of each farm $i$ in year $t$ :

$$
\Pi_{i j t}=\alpha_{j 0}+\sum_{l} \alpha_{j l} x_{l i t}+0.5 \sum_{l} \sum_{n} \alpha_{j l n} x_{l i t} x_{n i t}+\sum_{q} \alpha_{j q} z_{q i t}+\sum_{t} \alpha_{j t} D_{t}+\mu_{i j}+e_{i j t}
$$

\footnotetext{
${ }^{4}$ More specifically, Asche and Tveteras (1999) compare the LQ it to a Generalized Leontief function, which is also employed by Tveteras et al., (2011), and show that the specification does not matter. We have chosen the LQ over other specifications due to the more straightforward implementation w.r.t. the derivation of margins and their significance levels and better fit (e.g., expressed by AIC values).
} 
$\Pi_{i j t}$ with $j=1,2$ indicates revenues from the two outputs milk and sales of animals, while $\mathbf{x}_{\mathbf{i t}}$ is a vector of $l, n=1, \ldots, 5$ inputs. In addition to inputs, we control for the impact of animal health, climatic stress and milk quotas on mean output reflected by the variable set $\mathbf{z}_{\text {it }}$ (with $q=1, \ldots, 5$; presented in more detail in the next section). $D_{t}$ are time-specific dummy variables with $t=1, \ldots, 8$. Similarly, unobserved, timeinvariant farm-specific effects $\mu_{i j}$ which are treated as fixed effects, are added to the model using dummy variables (e.g., Baltagi and Blien 1998, McArthur and McCord 2017). $\alpha$ is the vector of the coefficients to be calculated. We assume that the error term $e_{i j t}$ is distributed with $E\left(e_{i j t}\right)=0, \operatorname{SVar}\left(e_{i j t}{ }^{-}\right)=$ $g_{j}\left(\mathbf{x}_{\mathbf{i t}} ; \mathbf{z}_{\mathbf{i t}} ; \mathbf{D}_{\mathbf{t}} ; \varepsilon_{i j t} ; \boldsymbol{\beta}\right)$ and $\operatorname{SCov}\left(e_{i 1 t}{ }^{-} ; e_{i 2 t}{ }^{-}\right)=g_{3}\left(\mathbf{x}_{\mathbf{i t}} ; \mathbf{z}_{\mathbf{i t}} ; \mathbf{D}_{\mathbf{t}} ; \varepsilon_{i t} ; \boldsymbol{\gamma}\right)$. Thus, both semi-variances and semi-covariance are functions of inputs, control variables, exogenous shocks ( $\varepsilon_{i j t}$ and $\varepsilon_{i t}$ ) as well as parameters to be estimated $(\boldsymbol{\beta} \text { and } \boldsymbol{\gamma})^{5}$ :

$$
\begin{aligned}
& \operatorname{SVar}\left(e_{i j t^{-}}\right)=\beta_{j 0}+\sum_{l} \beta_{j l} x_{l i t}+0.5 \sum_{l} \sum_{n} \beta_{j l n} x_{l i t} x_{n i t}+\sum_{q} \beta_{j q} z_{q i t}+\sum_{t} \beta_{j t} D_{t}+\varepsilon_{i j t} \\
& \operatorname{SCov}\left(e_{i 1 t^{-}} ; e_{i 2 t^{-}}\right)=\gamma_{0}+\sum_{l} \gamma_{l} x_{l i t}+0.5 \sum_{l} \sum_{n} \gamma_{l n} x_{l i t} x_{n i t}+\sum_{q} \gamma_{q} z_{q i t}+\sum_{t} \gamma_{t} D_{t}+\varepsilon_{i t}
\end{aligned}
$$

We assume no correlation of unobserved output shocks across farms or over time, i.e., $\operatorname{Cov}\left(e_{i j t} ; e_{p j t}\right)=$ 0 for $i \neq p$ and $\operatorname{Cov}\left(e_{i j t} ; e_{i j s}\right)=0$ for $t \neq s$.

Elasticity measures for the mean, semi-variance and semi-covariance functions with respect to inputs can be derived as follows:

$$
\begin{array}{ll}
\operatorname{MeanE}_{j l}=\frac{\partial f_{j}}{\partial x_{l}} \frac{x_{l}}{f_{j}} & \text { for mean output, } \\
\operatorname{SVarE}_{j l}=\frac{\partial g_{j}}{\partial x_{l}} \frac{x_{l}}{g_{j}} & \text { for output semi-variance, } \\
\operatorname{SCovE}_{12 l}=\frac{\partial g_{3}}{\partial x_{l}} \frac{x_{l}}{g_{3}} & \text { for output semi-covariance, }
\end{array}
$$

Positive (negative) elasticities with respect to input $l$ indicate that $l$ increases (decreases) revenue, downside risk, and the simultaneous occurrence of extreme risk events related to different outputs.

Presumably, exogenous shocks to milk production are simultaneously shocks to animal production and sales and vice versa which implies that the error terms of the equations defined by (9) and (10) are correlated. Previous studies (e.g., Tveteras et al., 2011) have therefore enhanced the estimation efficiency by estimating those equations as systems of seemingly unrelated regression equations (SURE). This accounts for potential correlation between the error terms of different outputs (Zellner 1962). However, we consider the same inputs and control variables for revenues from milk and animal sales so that SURE regressions do not improve the statistical efficiency of estimated parameters (Zellner 1962, 1963, Zellner and Huang 1962). Other studies (e.g., Du et al., 2015) account for possible cross-moment correlations by estimating a joint system of mean and variance equations based on the GMM estimator. This is based on the fact that in the Just and Pope (1978) stochastic production function framework, production risk appears as heteroscedasticity, rendering the OLS estimator inefficient. However, Asche and Tveteras (1999) show that when using heteroscedasticity, robust standard errors separating the estimation of mean and variance (semi-variance) functions can be superior as it permits a more detailed specification

\footnotetext{
${ }^{5}$ While farm-specific fixed effects are added to the mean function (see Eq. 9) to control for unobserved differences in technologies used, the subsequent estimation steps in Eq. 10-11 are based on residuals derived from this first estimation step. Thus, we assume no further unobserved differences across farms with respect to risk profiles and do not include farm-specific effects in the estimation of semi-variance and semi-covariance functions.
} 
based on less restrictive functional forms for individual equations. We therefore estimate the mean, semivariance and semi-covariance equations defined by (9), (10) and (11) separately.

, We use a two-stage least squares instrumental variable approach to produce consistent estimations and account for possible endogeneity problems caused by correlation of control variables in the set $\mathbf{z}_{\mathbf{i t}}$ with the error terms $e_{i j t}$.

\section{$3 \quad$ Data and background}

Our database consists of a panel of 390 dairy farms over the time span from 2007 to 2014. The farms are located in the German federal state North Rhine-Westphalia (see Figure A1 in the Appendix for a map of the location of farms). The Chamber of Agriculture of North Rhine-Westphalia provided the data based on farms receiving extension services (see Allendorf and Wettemann, 2015). This database contains both financial and biotechnological information for these farms as well as information on production and animal health. The information is available on the annual scale only. In a subsequent step, this dataset is matched with weather data (described below). The sample comprises farms with a homogenous milking technology. More specifically, all dairy farms utilize conventional, i.e., non-automated, milking systems. Moreover, farms use similar breeds, i.e., Holstein Friesian cattle (73\%), followed by Pezatta rosa cows (20\%), and crossbreeds (7\%). Farms self-select into the extension services feeding into the database used. Thus, this sample only represents specialized dairy farms and so the results cannot be upscaled to dairy production in North Rhine-Westphalia or Germany as a whole.

Annual revenues (in $€$ ) from milk and sales of animals are taken directly from the income statements of the farms. The latter comprise all revenues from selling animals, starting from the sale of calves and heifers through to dairy cows that no longer serve for milk production. The database provided no information on other income sources. However, in the case of the farms included in our analysis, we assume that milk and sales of animals generate the bulk of the farms' total revenues.

In line with the existing literature in this field (Antle and Goodger 1984, Key and Sneeringer 2014, Kumbhakar 1993, Orea and Wall 2011, Tveteras et al., 2011), we focus on the following production factors in our empirical analysis: i) land (in hectares, ha), ii) labor (in hours, h), iii) purchased concentrate feed (in $€$ total), iv) the total number of cattle, v) costs for material, machinery, and buildings (in $€$ ). Definitions and summary statistics of all variables are reported in Table 1 . In addition, we consider time dummies to account for technological change and control for general price developments. We assume that all inputs contribute to higher levels of milk and animal sales. Anticipated effects of production factors on risks are ambiguous, as earlier studies present contrasting results (Antle and Goodger 1984, Kumbhakar 1993, Orea and Wall 2011, Tveteras et al. 2011). However, these studies consistently show that a higher intensity of production, in our study expressed by larger expenditures for concentrate feed and a higher number of animals, increases the riskiness of production. Thus, we expect that larger and more intensive production that relies heavily on bought (concentrate) feed is characterized not only by higher average production but also by more vulnerable production systems. Finally, we control for the impact of farm related milk quotas measured in (energy corrected) kilogram (kg). No prior expectations can be deduced from earlier literature regarding the effect of inputs on the variability of sales of animals. However, Tveteras et al., (2011) show that all inputs with the exception of labor increase the variance of meat production.

In addition to the standard set of input variables described above, we also explicitly account for animal health and climate stress. Animal health cannot be measured directly, so we can only observe outcomes that arise from the animals' health status. For our analysis, these comprise i) somatic cell count, ii) the relative number of dead births ( $\mathrm{ndb}$ ), and iii) the relative number of animal losses (nal). Somatic cell count (scc)is a proxy for mastitis problems, one of the major animal health threats for dairy farms in Germany (Müller and Sauerwein, 2010). Furthermore, perinatal and postnatal mortality (reflected by nbd and nal) of dairy cattle represents a source of severe economic losses in European dairy production (e.g., Gundelach et al., 2009, Raboisson et al. 2013). 
We face potential endogeneity issues relating to these animal health variables, as they might be influenced by undetected management factors or other environmental factors (see e.g., Harmon 1994, for an overview). While time invariant components of these factors (e.g., related to animal housing) are captured by farm-specific fixed effects, the correlation with time variant factors (e.g., feeding and milking management) can cause endogeneity problems. We use a two-stage least squares 2SLS instrumental variable approach to cope with this. Lagged variables of scc, nal and ndb are considered as instruments. Moreover, we include lagged observations of key management variables that are expected to influence animal health as additional instruments. More specifically, we include lagged veterinary expenditure (in $€$ per cow) and the first calving age (herd average) because these are decisive for animal health and dairy herd management (e.g., Ettema and Santos 2004, Haworth et al. 2008). Veterinary expenditure might reflect preventive or curative measures to improve animal health (Antle and Goodger, 1984). Regarding first calving, Ettema and Santos (2004) show that if this occurs at an early age it is often associated with a higher incidence of stillbirths, as well as affecting other animal health related outcomes such as mastitis and in the end reduces milk yields and milk components. Animal health problems as well as the possible link between the first calving age and other performance relevant factors such as body weight (Ettema and Santos 2004), are expected to influence milk performance. This encourages its use as an instrument instead of including it the main equation. Moreover, Haworth et al., (2008) find that early first calving leads to an increase in health problems and a decline in the cow's life expectancy. The first calving age and veterinary expenditure are not included in the second stage regression analysis but serve only as instruments. We expect that low animal health status, as indicated by high levels of scc, nal and ndb, respectively, increases the downside risk related to milk sales (see e.g., Antle and Goodger 1984 and Harmon 1994). This is due to the fact that a higher probability of perinatal and postnatal mortalities plus situations where milk cannot be marketed (e.g., in cases of mastitis) imply more frequent deviations from the expected milk revenues. In this context, farmers also state that maintaining animal health can represent an important risk management strategy (e.g., Musser and Patrick, 2002). The expected effects of animal health on the anticipated milk sales are ambiguous. Animal health problems reduce potential sales of milk. However, there might also be trade-offs between animal health and expected milk sales. For example, although later first calving might imply better animal health it also lengthens the heifer's nonproductive time and thus increases total output (e.g., Ettema and Santos 2004, Hare et al., 2006, Lawson et al., 2004). In fact, in various countries there is a growing trend towards an earlier first calving age, which imply lower animal health but higher revenues (see e.g., Hare et al., 2006). Anticipated effects of scc, nal and $\mathrm{ndb}$ on sales of animals are ambiguous. We expect a negative effect since elevated disease rates in the population may mean that cows scheduled for sale have to be kept in order to maintain high milk production levels. However, high disease rates in the population leads to a larger number of nonproductive cows thus, depending on the infection frequency, it might also increase sales. Moreover, a growing number of mortality events are expected to increase volatility of the revenue streams from animal sales.

Like Key and Sneeringer $(2014$, ) we expect heat waves to be one of the most serious extreme climatic events for dairy producers, affecting both milk production and animal sales. Since both temperature and humidity must be considered jointly to depict perceived heat stress, we focus on temperature humidity indices (THI) in our analysis. We expect climate stress to reduce expected production levels and increase (downside) risks. In line with Bohmanova et al., (2007), we chose a THI index that is especially suited to our case study region (with low levels of humidity), i.e., with a particular emphasis on ambient temperature $^{6}$. We use daily maximum and minimum temperatures as well as relative humidity values to calculate daily $T H I_{\max } T H I_{\min }$ values. Like Bohmanova et al., (2007), we assume that the daily THI profile follows a sine curve between these two values and thus calculate the daily $T H I_{\text {load }}$ as the area between

6 More specifically, based on Bohmanova et al., (2007) we calculate the THI as: $T H I=\left(1.8 T_{d b}+32\right)-(0.55-$ $0.0055 R H)\left(1.8 T_{d b}-26\right)$ where, $T_{d b}$ and $R H$ denote dry bulb temperature [in degrees Celsius] and relative humidity [in percent], respectively. 
the THI sine curve and the $\mathrm{THI}_{\text {Threshold }}$ above which temperature stress is assumed to occur. The final THI value used in our analysis is an annual aggregate of daily $\mathrm{THI}_{\text {load }}$ values. The THI threshold values indicated in the literature vary between 70 to 78 (Dash et al., 2016, Igono et al., 1992, St-Pierre et al., 2003, Key and Sneeringer 2014). The results presented here are based on the threshold value of 75 but we also conducted sensitivity analyses with threshold values equal to 70 and 80 and obtained similar effects ${ }^{7}$. Farm-level data was matched with local weather data. For each farm we used the closest weather station that provides a complete time series of daily temperature and relative humidity information over the entire study period (Deutscher Wetterdienst 2016, Hill and Wall 2015). The resulting THI values show a large heterogeneity over space and time (see Figure 1 and Figure A2 in the Appendix, respectively). More specifically, we find that the THI load varies from almost zero to over 200 in our sample. Note that structural differences with respect to the climatic risk exposure of the farms are captured in the farmspecific fixed effects of our analysis. Furthermore, we are aware that heat stress also potentially affects the animal health related outcomes, such as animal losses, considered in our analysis (see e.g., Raboisson et al., 2013, Stull et al., 2008). However, the 2SLS approach used here does capture parts of the heat stress implications in the animal health proxies.

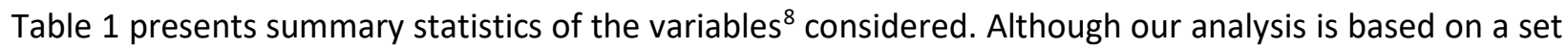
of farms with similar production techniques in North-Rhine Westphalia, we find that the factor endowment with land, labor, cattle and milk quotas differs largely across these farms. On average, the farms have about 86 ha of land under production and over 200 cattle. Moreover, we find animal sales to be important for our sample farms as they are naturally linked to dairy production and contribute almost $10 \%$ of the total revenues. In the Appendix, we present a correlation matrix of all variables (Table A1).

\section{< Table 1. Descriptive statistics >}

\section{< Figure 1. THI load for the year 2010. >}

\section{Results and discussion}

Table 2 presents elasticity and coefficient estimates for inputs ${ }^{9}$ and control variables ${ }^{10}$, respectively. Results for the mean functions specified by (Eq. 9) reveal that most inputs have a positive significant effect on the expected milk sales. In contrast, the production factor land has no significant effect on milk sales, indicating the relevance of the substitutability of the production factor land and concentrate feed in the production systems investigated here. In contrast, only a positive significant effect of concentrate feed is found for animal sales. The THI index has a significant negative effect on the expected levels of milk revenues. Thus, heat stress significantly affects dairy production, even in the highly developed, specialized dairy production in North Rhine-Westphalia. This highlights the need to develop adaptation strategies to cope with the effects of increasing climatic variability and more pronounced climatic extremes (e.g., Key and Sneeringer 2014). Figure 2 further illustrates the economic relevance of these effects. We used a simulation framework where the coefficient estimates of the impact of THI load 75 on milk revenues, as

\footnotetext{
${ }^{7}$ The full results of the sensitivity analysis with THI thresholds of 70 and 80 are available upon request. Note that the threshold of 80 only results in a limited number of heat stress observations.

8 Note that we removed two observations using multidimensional outlier detection based on the 'bacon' algorithm proposed by Billor et al., (2000). The bacon algorithm identifies outliers in a multidimensional framework based on Mahalanobis distances (Weber 2010). The two not considered observations were characterized by an implausibly large animal density per hectare, especially compared to pre- and succeeding observations of the same farms and thus probably represent errors in the data collection process.

${ }^{9}$ See Table A3 in the Appendix for coefficients of the input interaction terms.

${ }^{10}$ As regards model diagnostics, Wald tests (for mean functions estimated with 2SLS) and F-tests (for semi-variance and semicovariance functions estimated with OLS) reveal the overall significance of all models. Variance inflation factors reveal no indication for multicollinearity. Furthermore, the qualitative interpretation of results does not change if individual potentially correlated variables are removed.
} 
displayed in Table 2, have been multiplied by the historical THI exposure of each farm and year ${ }^{11}$. Shaded areas stretch from minimum and maximum values observed at individual farms, whereas the solid line shows the estimated average effect across farms. This figure reveals the high economic impact of the THI, with average heat stress induced losses in milk revenues amounting to about 10,000€ per year, while it can exceed 25,000€ per year for individual farms. The simulations in Figure 2 further highlight the substantial degree of heterogeneity of heat stress induced effects across time and space.

In addition, milk quotas are found to significantly increase expected levels of dairy revenues. Note, however, that quota levels are not strictly binding and farms in our sample over- and underuse their quota levels significantly. Thus, the quota level is not the only predictor for milk revenues. On average, the quota use is at a level of $108 \%$, with a high level of heterogeneity across farms (see also Table 1$)^{12}$.

\section{< Figure 2: Historical simulation of impact of THI load 75 on milk revenues >}

Animal health variables reflect a significant negative effect of the scc on expected milk revenues. In contrast, higher relative animal losses are associated with an increase of the expected milk revenues. This finding highlights the potential trade-off in the interrelation between animal health and revenues. For example, this might reflect that first calving at a later age might improve animal health and reduce animal losses but also decreases expected revenues due to forgone lactating periods. We find animal losses only have a significant positive effect with regard to expected animal sales. In general, lower animal health might be correlated with a higher turnover of animals, leading to more frequent sales.

Both mean functions were estimated using a 2 SLS instrumental variable approach to account for the possible endogeneity of the variables ssc, nal and ndb, whereby the insignificant Sargan test statistics indicate that the overidentifying restrictions are not rejected. ${ }^{13}$ Furthermore, we assess the relevance of the instruments included based on the minimum eigenvalue statistic by Cragg and Donald (2002) which constitutes the adequate measure if the number of endogenous regressors is larger than one. The null hypothesis of weak instruments is rejected ${ }^{14}$ for both the mean milk and animal sales functions. This implies that lagged values of scc, nal, ndb as well as the lagged values of the first calving age and veterinary expenditure constitute valid and relevant instruments. Note that the inclusion of lagged explanatory variables, or the use of these variables as instruments in a 2SLS framework, only purges estimates of endogeneity if i) autocorrelation among the residuals is not present (e.g., Ansell, 2008; Bellemare et al., 2017; Betz et al., 2018) and ii) if the lagged values are themselves not present as explanatory factors in the main equation (e.g., Reed, 2015). We therefore apply Arellano and Bond`s (1991) AR test which is particularly suited to assess the presence of autocorrelation in the residuals of 2SLS estimations. The bottom line of Table 2 indicates that the null hypothesis of no autocorrelation is not rejected for either of the mean functions relating to both the mean milk and mean meat estimation. This confirms the appropriateness of using lags as instruments. Moreover, the argumentation of causality in our instrumentation strategy as presented above encourages the use of these variables as instruments instead of their inclusion in the main equation.

Estimates for the semi-variance functions specified by (10) are presented in the third and fifth column of Table 2. Moreover, the effects of selected variables (number of cattle, labor and concentrate feed) on expected revenues (absolute effects) and semi-variance (marginal effects) are illustrated in Figure 3 (the graphs for all variables are given in the Appendix). Figure 3 thus reveals the heterogeneities in the effects

\footnotetext{
11 Note that the approach chosen here probably underestimates the effects of heat stress on revenues because our econometric model also accounts for year dummies. Therefore, systemic events such as a heat waves are partly captured in the year dummy (that also includes other effects such as price shocks) and the THI effect that is presented here.

${ }^{12} \mathrm{~A}$ super levy must be paid if quota levels are exceeded (see e.g. Francksen, et al., 2012).

${ }^{13}$ In both cases Sargan tests of overidentifying restrictions are highly insignificant indicating that the selected instruments are orthogonal to the errors and hence valid.

${ }^{14}$ First stage regression results of the 2SLS mean functions are reported in the Appendix (Table A2)
} 
on both expected revenues and semi-variance across realizations of the respective variables in our sample (represented as histograms).

Our results show that land significantly increases the semi-variance of milk revenues, i.e., is (downside) risk increasing, while the coefficients of other inputs such as labor and concentrate feed are positive as indicated in earlier studies (e.g., Tveteras et al., 2011, Kumbhakar 1993, Orea and Wall 2011), but these coefficients are not significant in our analysis.

\section{< Figure 3: Impact of inputs on expected revenues (absolute effects) and semi-variance (marginal effects) of milk production and animal sales $>$}

The impact of the number of cattle on downside risks is expected to have two relevant effects. Firstly, in the case of idiosyncratic risks affecting only individual animals, a larger herd size implies that aggregating over a larger number of individual production units leads to a reduction of total variability (see e.g., Marra and Schurle 1994, for examples of crop production). Secondly, in the case of systemic risks affecting all the animals in the entire herd equally, larger herd sizes may imply an increasing risk. Our results show that - on average - the former effect dominates for milk revenues, i.e., a larger number of cattle reduces risk. However, the effects of herd size on downside risks are found to be non-uniform across all farms. A closer look at the impact of the number of cattle reveals that the respective effect on milk revenues varies across herd sizes (holding all other variables at their respective average value; see third column of Figure 3). More specifically, with increasing herd sizes, the risk reducing effect vanishes.

We find the number of cattle increases the semi-variance of animal sales, confirming the results of Tveteras et al., (2011). Thus, the total effect of the herd size on risk exposure at the farm-level remains ambiguous as milk revenue variability decreases and the variability of animal sales increases. Again, this effect is not uniform across herd sizes. Figure 3 shows that the number of cattle decreases semi-variance for herd sizes of less than about 120, but increases semi-variance for larger herds. Furthermore, we find that labor input decreases downside risks in animal sales revenues, which is in line with findings of Tveteras et al., (2011) (for meat sales).

In addition, we find clear indications that animal health affects semi-variances of milk and animal sales. More specifically, we find a significant positive effect of the share of animal losses and dead births on the semi-variance of milk revenues, which indicates that lower animal health status leads to higher downside risk exposure. In contrast, we find the semi-variance of milk sales decreases with increasing scc. Regarding the semi-variance of animal sales, we find a downside risk increasing effect of the share of animal losses, while the scc reduces the semi-variance of animal sales.

In the case of heat stress, the THI index was found to have no significant effect on the semi-variance of milk revenues, even though it has a significant impact on production levels. This result might be due to the fact that there were very few extreme climatic events during the sample period in our analysis. However, a higher THI index is found to increase the semi-variance of animal sales. This result could indicate that in heat stress situations, animal sales are possibly postponed to maintain milk production. Milk quotas do not influence the degree of extreme risks related to both milk and animal sales.

Finally, the semi-covariance function (Eq. 11) reveals that the number of animal losses, farm land and concentrate feed expenditure increase the semi-covariance, i.e., further increase the downside risk exposure of dairy farms as the probability of concurrent occurrence of below-average outcomes in milk and animal sales rises.

\section{< Table 2. Elasticity estimates with THI and animal health factors >}




\section{Conclusion}

Our analysis for dairy farms in North-Rhine Westphalia (Germany) reveals significant effects of production inputs on expected revenues from both milk and animal sales. The effects of inputs on semi-variances remain inconclusive but reveal that not all inputs affect dairy farms' risk uniformly. For instance, different input variables have been identified to influence downside risk exposure for milk and animal sales. Moreover, we find that herd size (on average) decreases the downside risks in milk revenues, but increases downside risks in animal sales. Thus, the risk effects of inputs or control variables can be outweighed or amplified when analyzing them in a joint system. Furthermore, we find farm land and expenditure for concentrate feed increase the semi-covariance, i.e., to c.p. increase the likelihood of a joint occurrence of below-average outcomes in milk and animal sales. Therefore, our analysis highlights the relevance of a holistic farm-level risk assessment that also accounts for non-milk outputs that naturally occur at dairy farms. Furthermore, the findings on the semi-covariance partly support the hypothesis that intensive production methods based strongly on concentrate feed are more vulnerable.

We find that animal health is an integral component of both expected revenues and production risks. More specifically, a higher somatic cell count results in lower milk revenues. In contrast, a higher number of animal losses is associated with higher dairy and animal sales but also increases the semi-variance of the revenues generated by both outputs. This highlights the potential trade-offs in animal health between expected revenues and downside risk exposure. Thus, risk averse decision makers will choose management measures (e.g., later first calving ages), that reduce animal losses and lead to lower downside risk exposure but, at the same time, imply opportunity costs in terms of forgone revenues. This finding also outlines potential critical effects of the subsidization of risk management tools such as the Income Stabilization Tool (e.g., El Benni et al., 2016) currently under discussion. More specifically, provision against income variability might encourage more risky production decisions, implying that lower levels of animal health are the best choice.

Finally, we find that heat stress has a significant negative effect on milk revenues. Even though the farms studied here operate under highly professional conditions and use state of the art technologies, extreme climatic events have marked economic effects on milk revenues. The economic relevance of these heat stress events is expected to increase even further due to climate change and must therefore be accounted for in long-term investment decisions. Risk management instruments tailored to heat stress, e.g., using index insurance solutions, can be developed based on the marginal effects of heat stress on dairy farm revenues indicated here (e.g., Deng et al., 2007, Vermeulen et al., 2012). The role of risk preferences across farms must be studied more closely. To this end, econometric analysis should be combined with experimental approaches to elicit risk preferences (e.g., Vollmer et al., 2017). Moreover, future analysis also should consider adjustments at the household level involving the use of resources (e.g., labor and land) off the farm (e.g., de Mey et al., 2016). 


\section{Literature}

Allendorf, J. and Wettemann, P. (2015). Does animal welfare influence dairy farm efficiency? A twostage approach. Journal of Dairy Science, Vol. 98 (11): 7730-7740.

Ansell, B.W. (2008). Traders, Teachers, and Tyrants: Democracy, Globalization, and Public Investment in Education. International Organization 62: 289-322.

Antle, J. M. (1983). Testing the stochastic structure of production: a flexible moment-based approach. Journal of Business \& Economic Statistics 1(3): 192-201.

Antle, J. M. (2010). Asymmetry, partial moments and production risk. American Journal of Agricultural Economics, 92(5), 1294-1309.

Antle, J. M. and Goodger, W. J. (1984). Measuring stochastic technology: the case of Tulare milk production. American Journal of Agricultural Economics 66(3): 342-350.

Arellano, M. and Bond, S. (1991). Some tests of specification for panel data: Monte Carlo evidence and an application to employment equations. The Review of Economic Studies 58: 277-97.

Asche, F. and Tveterås, R. (1999). Modeling production risk with a two-step procedure. Journal of Agricultural and Resource Economics 24(2): 424-439.

Baltagi, B.H. and Blien, U. (1998). The German wage curve: evidence from the IAB employment sample. Economic Letters 61: 135-142.

Bellemare, M.F., Masaki, T., and Pepinsky, T.B. (2017). Lagged Explanatory Variables and the Estimation of Causal Effect. The Journal of Politics 79(3): 949-963

Berentsen, P. B. M., Kovacs, K. and Van Asseldonk, M. A. P. M. (2012). Comparing risk in conventional and organic dairy farming in the Netherlands: an empirical analysis. Journal of Dairy Science 95(7): 38033811.

Betz, T., Cook, S.J., and Hollenbach, F.M. (2018). On the Use and Abuse of Spatial Instruments. Political Analysis (forthcoming).

Billor, N., A. S. Hadi, and Velleman, P.F. (2000). BACON: Blocked adaptive computationally efficient outlier nominators. Computational Statistics \& Data Analysis 34: 279-298.

Bohmanova, J., Misztal, I. and Cole, J. B. (2007). Temperature-humidity indices as indicators of milk production losses due to heat stress. Journal of Dairy Science 90(4): 1947-1956.

Bouamra-Mechemache, Z., Jongeneel, R. and Réquillart, V. (2008). Impact of a gradual increase in milk quotas on the EU dairy sector. European Review of Agricultural Economics (4): 461-491.

Chen, G., Roberts, M. C. and Thraen, C. S. (2006). Managing dairy profit risk using weather Derivatives. Journal of Agricultural and Resource Economics 31(3): 653-666.

Cragg, J. G., and Donald, S.G. (1993). Testing identifiability and specification in instrumental variable models. Econometric Theory 9: 222-240.

Curtis, S. E. (2007). COMMENTARY: Performance Indicates Animal State of Being: A Cinderella Axiom? The Professional Animal Scientist 23(6): 573-583.

D'Antoni, J. and Mishra, A. K. (2012). Determinants of dairy farmers' participation in the Milk Income Loss Contract program. Journal of Dairy Science 95(1): 476-483. 
Dash, S., Chakravarty, A.K., Singh, A., Upadhyay, A., Singh, M. and Yousuf, S. (2016). Effect of heat stress on reproductive performances of dairy cattle and buffaloes: A review. Veterany World 9(3): 235 - 244 .

De Mey, Y., Wauters, E., Schmid, D., Lips, M., Vancauteren, M., and Van Passel, S. (2016). Farm household risk balancing: empirical evidence from Switzerland. European Review of Agricultural Economics, 43(4), 637-662.

Deng, X., Barnett, B. J., Vedenov, D. V., \& West, J. W. (2007). Hedging dairy production losses using weather-based index insurance. Agricultural Economics, 36(2), 271-280.

Deutscher Wetterdienst, 2016. FTP Server. Available at ftp://ftp.dwd.de/. Accessed 24.08.2016.

Di Falco, S. and Chavas, J. P. (2006). Crop genetic diversity, farm productivity and the management of environmental risk in rainfed agriculture. European Review of Agricultural Economics 33(3): 289-314.

Driscoll, P, McGuirk, A. and Alwang, J. (1992). Testing Hypotheses of Functional Structure: Some Rules for Determining Flexibility of Restricted Production Models. American Journal of Agricultural Economics 74(1): 100-108.

Du, X., Yu, C.L., Hennessy, D.A. and Miao, R. (2015). Geography of crop yield skewness. Agricultural Economics 46: 463-473.

El Benni, N. and Finger, R. (2013). Gross Revenue risk in Swiss dairy farming. Journal of Dairy Science 96(2): 936-948

El Benni, N., Finger, R. and Meuwissen, M. (2016). Potential effects of the Income Stabilization Tool (IST) in Swiss agriculture. European Review of Agricultural Economics 43: 475-502

Ettema, J. F. and Santos, J. E. P. (2004). Impact of age at calving on lactation, reproduction, health, and income in first-parity Holsteins on commercial farms. Journal of Dairy Science 87(8): 2730-2742.

Estrada, J. (2004). Mean-Semivariance Behaviour: An Alternative Behavioural Model. Journal of Emerging Market Finance 3(3): 231-248.

Estrada, J. (2007). Mean-semivariance behavior: Downside risk and capital asset pricing. International Review of Economics \& Finance 16(2): 169-185.

Francksen, T., Hagemann, M. and Latacz-Lohmann, U. (2012). Growth of milk production in German dairy farms: an empirical study based on event history analysis. Agricultural Economics 43(6): 671-685.

Gatzert, N., \& Kling, A. (2007). Analysis of participating life insurance contracts: A unification approach. Journal of Risk and Insurance, 74(3), 547-570.

Gundelach, Y., Essmeyer, K., Teltscher, M. K., \& Hoedemaker, M. (2009). Risk factors for perinatal mortality in dairy cattle: Cow and foetal factors, calving process. Theriogenology, 71(6), 901-909.

Hansson, H., \& Lagerkvist, C. J. (2014). Decision Making for Animal Health and Welfare: Integrating RiskBenefit Analysis with Prospect Theory. Risk Analysis, 34(6), 1149-1159.

Hare, E. H. D. N., Norman, H. D. and Wright, J. R. (2006). Trends in calving ages and calving intervals for dairy cattle breeds in the United States. Journal of Dairy Science 89(1): 365-370.

Harmon, R. J. (1994). Physiology of mastitis and factors affecting somatic cell counts. Journal of Dairy Science 77(7): 2103-2112. 
Henry, G. W., Boyer, C. N., Griffith, A. P., Larson, J., Smith, A. and Lewis, K. (2016). Risk and Returns of Spring and Fall Calving for Beef Cattle in Tennessee. Journal of Agricultural and Applied Economics 48 (3): 257-278

Hill, D. L. and Wall, E. (2015). Dairy cattle in a temperate climate: the effects of weather on milk yield and composition depend on management. Animal 9(1): 138-149.

Hirsch, S. and Hartmann, M. (2014). Persistence of firm-level profitability in the European dairy processing industry. Agricultural Economics 45(S1): 53-63.

Igono, M. O., Bjotvedt, G. and Sanford-Crane, H. T. (1992). Environmental profile and critical temperature effects on milk production of Holstein cows in desert climate. International Journal of Biometeorology 36(2): 77-87.

Jarrow, R., and Zhao, F. (2006). Downside loss aversion and portfolio management. Management Science, 52(4), 558-566.

Just, R. E. and Pope, R. D. (1978). Stochastic specification of production functions and economic implications. Journal of Economics 7(1): 67-86.

Kadzere, C. T., Murphy, M. R., Silanikove, N. and Maltz, E. (2002). Heat stress in lactating dairy cows: a review. Livestock Production Science 77(1): 59-91.

Key, N. and Sneeringer, S. (2014). Potential Effects of Climate Change on the Productivity of US Dairies. American Journal of Agricultural Economics 96(4): 1136-1156.

Kim, K., Chavas, J. P., Barham, B., and Foltz, J. (2014). Rice, irrigation and downside risk: a quantile analysis of risk exposure and mitigation on Korean farms. European Review of Agricultural Economics 41(5): 775-815.

Koundouri, P., Laukkanen, M., Myyrä, S. and Nauges, C. (2009). The effects of EU agricultural policy changes on farmers' risk attitudes. European Review of Agricultural Economics 36 (1): 53-77.

Kumbhakar, S. C. (1993). Production risk, technical efficiency, and panel data. Economic Letters 41(1): 11-16.

Lusk, J. L. and Norwood, F. B. (2011). Animal welfare economics. Applied Economic Perspectives and Policy 33(4): 463-483.

Marra, M. C. and Schurle, B. W. (1994). Kansas wheat yield risk measures and aggregation: a metaanalysis approach. Journal of Agricultural and Resource Economics 19(1): 69-77.

McArthur, J.W. and McCord, G.C. (2017). Fertilizing growth: Agricultural inputs and their effects in economic development. Journal of Development Economies 127: 133-152.

Miranda, M. J., and Glauber, J. W. (1991). Providing crop disaster assistance through a modified deficiency payment program. American journal of agricultural economics 73(4): 1233-1243.

Müller, U., and Sauerwein, H. (2010). A comparison of somatic cell count between organic and conventional dairy cow herds in West Germany stressing dry period related changes. Livestock Science, 127(1), 30-37.

Musser, W. N., and Patrick, G. F. (2002). How much does risk really matter to farmers? In Just, R.E. and Pope, R.D. (eds) A comprehensive assessment of the role of risk in US agriculture (pp. 537-556). Springer, Boston, USA. 
Oltenacu, P. A. and Broom, D. M. (2010). The impact of genetic selection for increased milk yield on the welfare of dairy cows. Animal Welfare 19(1): 39-49.

Orea, L. and Wall, A. (2012). Productivity and producer welfare in the presence of production risk. Journal of Agricultural Economics 63(1): 102-118.

Raboisson, D., Delor, F., Cahuzac, E., Gendre, C., Sans, P., and Allaire, G. (2013). Perinatal, neonatal, and rearing period mortality of dairy calves and replacement heifers in France. Journal of Dairy Science, 96(5), 2913-2924.

Reed, W.R. (2015). On the Practice of Lagging Variables to Avoid Simultaneity. Oxford Bulletin of Economics and Statistics 77(6): 897-905.

Saastamoinen, A. (2015). Heteroscedasticity or production risk? a synthetic view. Journal of Economic Surveys 29(3): 459-478.

Schmit, T.M., Boisvert, R.N. and Tauer, L.W. (2001). Measuring the financial risks of New York dairy producers. Journal of Dairy Science 84: 411-420

St-Pierre N. R., Cobanov B. and Schnitkey G. (2003). Economic Loss from Heat Stress by US Livestock Industries. Journal of Dairy Science 86 E Suppl.: E52-E77.

Stull, C. L., Messam, L. M., Collar, C. A., Peterson, N. G., Castillo, A. R., Reed, B. A., Andersen, K.L., VerBoort, W. R. (2008). Precipitation and temperature effects on mortality and lactation parameters of dairy cattle in California. Journal of dairy science, 91(12), 4579-4591.

Tubiello, F. N., Soussana, J. F. and Howden, S. M. (2007). Crop and pasture response to climate change. PNAS 104(50): 19686-19690.

Tveteras, R., Flaten, O. and Lien, G. (2011). Production risk in multi-output industries: estimates from Norwegian dairy farms. Applied Economics 43(28): 4403-4414.

Valvekar, M., Chavas, J. P., Gould, B. W. and Cabrera, V. E. (2011). Revenue risk management, risk aversion and the use of Livestock Gross Margin for Dairy Cattle insurance. Agricultural Systems 104(9): 671-678.

Vedenov, D. V. and Barnett, B. J. (2004). Efficiency of weather derivatives as primary crop insurance instruments. Journal of Agricultural and Resource Economics 29(3): 387-403.

Vermeulen, S.J., Aggarwal, P.K. Ainslie, A. Angelone, C. Campbell, B.M. Challinor, A.J., Hansen, J.W., Ingram, JSI, Jarvis, A. Kristjanson, P., Lau, C. Nelson, G.C., Thornton, P.K., Wollenberg, E. (2012). Options for support to agriculture and food security under climate change. Environmental Science \& Policy, 15(1), 136-144.

Vollmer, E., Hermann, D., and Mußhoff, O. (2017). Is the risk attitude measured with the Holt and Laury task reflected in farmers' production risk? European Review of Agricultural Economics, 44 (3): 399-424.

Wolf, C. A., Black, R.J. and Hadrich, J. C. (2009). Upper Midwest dairy farm revenue variation and insurance implications. Agricultural Finance Review 69(3): 346-358.

Weber, S. (2010). bacon: An effective way to detect outliers in multivariate data using Stata (and Mata). The Stata Journal 10(3): 331-338.

Zellner, A. (1962). An efficient method of estimating seemingly unrelated regressions and tests for aggregation bias. Journal of the American Statistical Association 57: 348-368. 
Zellner, A. (1963). Estimators for seemingly unrelated regression equations: Some exact finite sample results. Journal of the American Statistical Association 58: 977-992.

Zellner, A. and Huang, D. S. (1962). Further properties of efficient estimators for seemingly unrelated regression equations. International Economic Review 3: 300-313. 
Table 1. Descriptive statistics

\begin{tabular}{|c|c|c|c|c|c|}
\hline Variable & Definition & Mean & SD & Min & Max \\
\hline 1 Milk & Milk output (revenues in $€ \mathrm{EC}$ ) & 308834.20 & 194977.90 & 43948.00 & 2576725.00 \\
\hline 2 Animal sales & Animal sales (revenues in $€$ ) & 31231.01 & 21627.04 & 3258.01 & 355383.91 \\
\hline 3 Land & Farm land (ha) & 85.66 & 38.29 & 21.48 & 333.29 \\
\hline 4 Labor & Labor (hours) & 4076.61 & 1732.63 & 1371.22 & 20318.00 \\
\hline 5 Feed & Purchased concentrate feed $(€)$ & 69859.72 & 50.969 .77 & 1486.86 & 684227.30 \\
\hline 6 No. of cattle & No. of cattle & 202.87 & 101.50 & 40.21 & 1138.90 \\
\hline 7 Costs & $\begin{array}{c}\text { Costs for material, machinery, and } \\
\text { buildings }(€)\end{array}$ & 77894.80 & 50593.16 & 13945.00 & 589589.40 \\
\hline $\begin{array}{l}8 \text { Somatic cell } \\
\text { count }\end{array}$ & Number of somatic cells (th) & 201.84 & 53.51 & 16 & 487 \\
\hline 9 Animal losses & Number of animal losses (in \%) & 3.50 & 2.90 & 0 & 23.9 \\
\hline 10 Dead births & Number of dead births (in \%) & 5.48 & 4.24 & 0 & 38.57 \\
\hline $11 \mathrm{THI}$ load 75 & Temperature and humidity index 75 & 57.21 & 30.37 & 0.59 & 202.12 \\
\hline 12 Milk quota & Milk quota $\mathrm{EC}(\mathrm{kg})$ & 774892.60 & 414412.50 & 180659.00 & 4500000.00 \\
\hline 13 First calving age & First calving age (month) & 28.06 & 2.17 & 22.60 & 41.40 \\
\hline $\begin{array}{l}14 \text { Veterinary } \\
\text { expenditure }\end{array}$ & Veterinary expenditure ( $€ /$ cow $)$ & 120.27 & 51.20 & 11.36 & 383.96 \\
\hline Milk semi-variance & & $3.03 e 9$ & $8.44 \mathrm{e} 9$ & 645.27 & $2.66 \mathrm{e} 11$ \\
\hline Meat semi-variance & & $1.06 \mathrm{e} 8$ & $2.44 \mathrm{e} 8$ & 3.36 & $4.08 \mathrm{e} 9$ \\
\hline Semi-covariance & & $4.30 \mathrm{e} 8$ & $1.03 e 9$ & 30547.17 & $2.19 \mathrm{e} 10$ \\
\hline No. of farms*** & 390 & & & & \\
\hline No. of obs. & 3118 & & & & \\
\hline
\end{tabular}

Note: All monetary values are adjusted for the value-added tax. Based on the requirements for weather stations presented above, the THI was calculated based on an overall number of 15 weather stations for the 390 farms. The number of cattle is measured as livestock units where calves and young animals ( $<1$ year) equal 0.3 units, $<2$ years 0.7 units and remaining animals 1 unit. 
Table 2. Input elasticity estimates and regression coefficients for THI, milk quota and animal health factors

\begin{tabular}{|c|c|c|c|c|c|}
\hline \multirow[b]{2}{*}{$\begin{array}{l}\text { Inputs/control } \\
\text { variables }\end{array}$} & \multicolumn{2}{|c|}{ Milk } & \multicolumn{2}{|c|}{ Animal sales } & \multirow[b]{2}{*}{ Semi-covariance } \\
\hline & Mean & $\begin{array}{c}\text { Semi- } \\
\text { variance }\end{array}$ & Mean & Semi-variance & \\
\hline \multicolumn{6}{|l|}{ Elasticities } \\
\hline Land & $\begin{array}{l}-0.010 \\
(0.037)\end{array}$ & $\begin{array}{c}0.773 * * \\
(0.331)\end{array}$ & $\begin{array}{c}0.097 \\
(0.129)\end{array}$ & $\begin{array}{l}-0.370 \\
(0.270)\end{array}$ & $\begin{array}{l}0.542 * \\
(0.291)\end{array}$ \\
\hline Labor & $\begin{array}{c}0.113^{* * *} \\
(0.029)\end{array}$ & $\begin{array}{c}0.519 \\
(0.533)\end{array}$ & $\begin{array}{c}0.029 \\
(0.093)\end{array}$ & $\begin{array}{c}-1.011^{*} \\
(0.569)\end{array}$ & $\begin{array}{l}-0.615 \\
(0.475)\end{array}$ \\
\hline Feed & $\begin{array}{c}0.333^{* * *} \\
(0.034)\end{array}$ & $\begin{array}{c}0.871 \\
(0.609)\end{array}$ & $\begin{array}{c}0.338 * * * \\
(0.084)\end{array}$ & $\begin{array}{c}0.283 \\
(0.673)\end{array}$ & $\begin{array}{l}0.958 * \\
(0.563)\end{array}$ \\
\hline No. of cattle & $\begin{array}{c}0.161^{* * *} \\
(0.045)\end{array}$ & $\begin{array}{c}-2.838 * * \\
(1.393)\end{array}$ & $\begin{array}{c}0.219 \\
(0.153)\end{array}$ & $\begin{array}{c}1.126 * * \\
(0.509)\end{array}$ & $\begin{array}{l}-0.872 \\
(0.661)\end{array}$ \\
\hline Costs & $\begin{array}{c}0.119 * * * \\
(0.024)\end{array}$ & $\begin{array}{c}0.472 \\
(0.576)\end{array}$ & $\begin{array}{l}-0.092 \\
(0.071)\end{array}$ & $\begin{array}{c}0.127 \\
(0.879)\end{array}$ & $\begin{array}{c}0.155 \\
(0.460)\end{array}$ \\
\hline \multicolumn{6}{|l|}{ Regression coefficients } \\
\hline THI load 75 & $\begin{array}{c}-167.361 * * * \\
(51.782)\end{array}$ & $\begin{array}{c}2.84 \mathrm{e} 6 \\
(5.55 \mathrm{e} 6)\end{array}$ & $\begin{array}{c}10.251 \\
(16.577)\end{array}$ & $\begin{array}{l}3.88 \mathrm{e} 5^{*} \\
(2.10 \mathrm{e} 5)\end{array}$ & $\begin{array}{c}6.86 \mathrm{e} 5 \\
(7.76 \mathrm{e} 5)\end{array}$ \\
\hline Somatic cell count & $\begin{array}{c}-228.150 * * \\
(98.711)\end{array}$ & $\begin{array}{c}-5.92 \mathrm{e}^{* * * *} \\
(2.22 \mathrm{e} 6)\end{array}$ & $\begin{array}{c}4.181 \\
(31.600)\end{array}$ & $\begin{array}{c}-1.57 \mathrm{e} 5^{*} \\
(9.51 \mathrm{e} 4)\end{array}$ & $\begin{array}{l}-4.18 \mathrm{e} 5 \\
(3.51 \mathrm{e} 5)\end{array}$ \\
\hline Animal losses & $\begin{array}{c}5821.383 * * \\
(2494.783)\end{array}$ & $\begin{array}{c}3.29 \mathrm{e} 8 * * * \\
(3.98 \mathrm{e} 7)\end{array}$ & $\begin{array}{c}1772.818^{* *} \\
(760.881)\end{array}$ & $\begin{array}{c}1.18 \mathrm{e} 7 * * * \\
(1.83 \mathrm{e} 6)\end{array}$ & $\begin{array}{c}5.94 \mathrm{e} 7 * * * \\
(7.81 \mathrm{e} 6)\end{array}$ \\
\hline Dead births & $\begin{array}{c}250.048 \\
(1893.67)\end{array}$ & $\begin{array}{c}6.08 \mathrm{e} 7 * * \\
(2.66 \mathrm{e} 7)\end{array}$ & $\begin{array}{l}-433.959 \\
(563.841)\end{array}$ & $\begin{array}{l}-9.85 e 5 \\
(1.03 e 6)\end{array}$ & $\begin{array}{c}5.54 \mathrm{e} 6 \\
(4.45 \mathrm{e} 6)\end{array}$ \\
\hline Milk quota & $\begin{array}{c}0.103^{* * *} \\
(0.027)\end{array}$ & $\begin{array}{c}1553.617 \\
(1443.749)\end{array}$ & $\begin{array}{c}0.001 \\
(0.005)\end{array}$ & $\begin{array}{c}83.804 \\
(63.736)\end{array}$ & $\begin{array}{c}234.581 \\
(193.063)\end{array}$ \\
\hline $\mathrm{F}$ & & 25.340 & & 5.220 & 9.340 \\
\hline$p$-value & & 0.000 & & 0.000 & 0.000 \\
\hline Wald $x 2$ & 80281.48 & & 8041.70 & & \\
\hline Sargan $\chi 2$ & 1.473 & & 0.064 & & \\
\hline$p$-value & 0.479 & & 0.969 & & \\
\hline $\mathrm{n}$ & 2,630 & 1,706 & 2,630 & 1,573 & 1,001 \\
\hline \multicolumn{6}{|l|}{ First stage statistics } \\
\hline Min. eigenvalue stat. & 4.607 & & 4.607 & & \\
\hline Critical value & 4.300 & & 4.300 & & \\
\hline $\begin{array}{l}\text { Arellano and Bond } \\
A R(1)\end{array}$ & $\begin{array}{c}z=1.03 \\
p=0.305\end{array}$ & & $\begin{array}{c}z=0.42 \\
p=0.677\end{array}$ & & \\
\hline
\end{tabular}

Notes: Values for inputs (land, labor, feed, no. of cattle, and costs) are output elasticities w.r.t. those inputs; values for somatic cell count, calving age, THI load 75, and milk quota are regression coefficients.

Heteroskedasticity robust standard errors in parentheses.

$*, * *, * * *$ indicates significance at the 10,5 , and $1 \%$ - level, respectively. 


\section{THI Load 75}

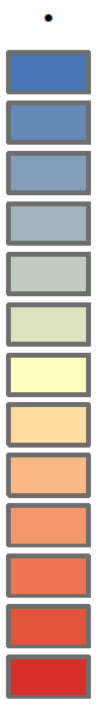
Farm
$2-12$
$13-23$
$24-34$
$35-44$
$45-55$
$56-66$
$67-76$
$77-87$
$88-98$
$99-109$
$110-119$
$120-130$
$131-141$

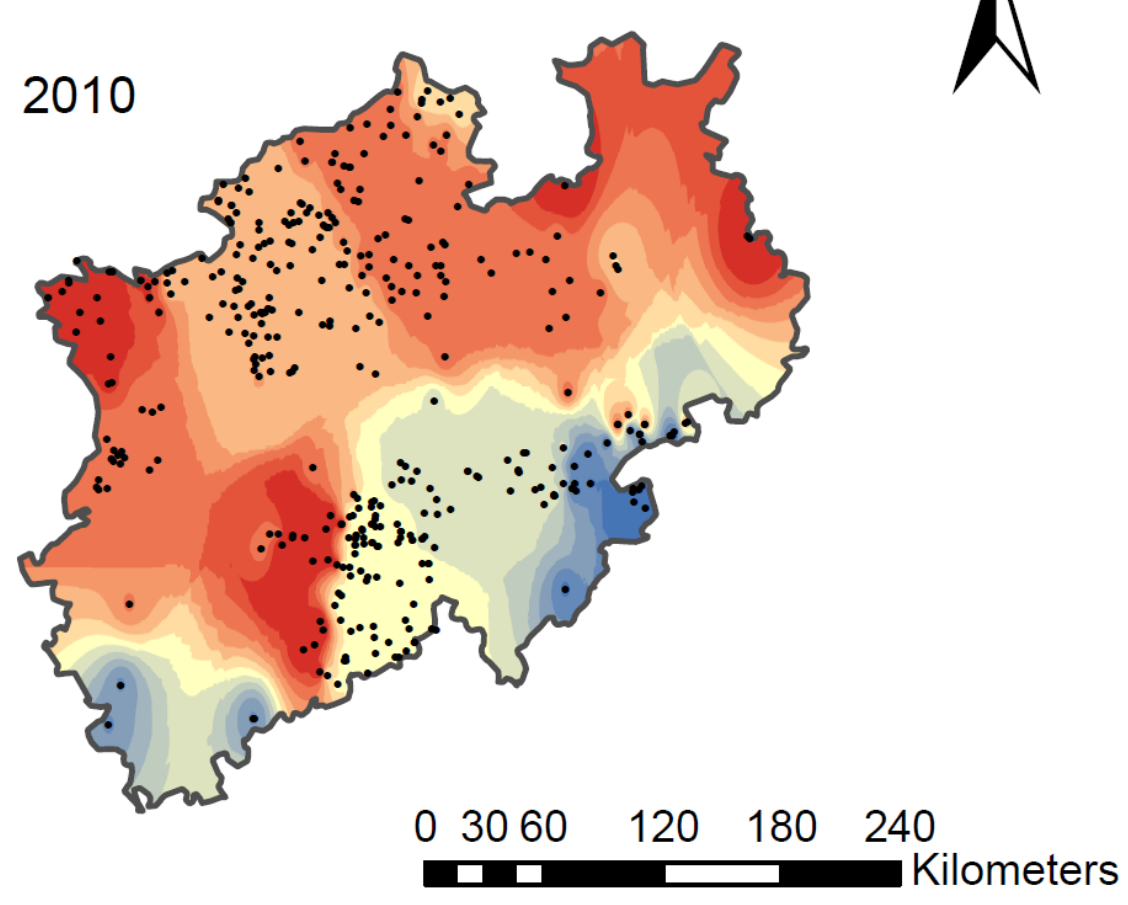

Note: points represent the location of each farm and the color indicates the THI load (legend in Figure). See Figure A1 in the Appendix for a presentation of the farms' location in Germany as a whole. 
Figure 2: Historical simulation of impact of THI load 75 on milk revenues

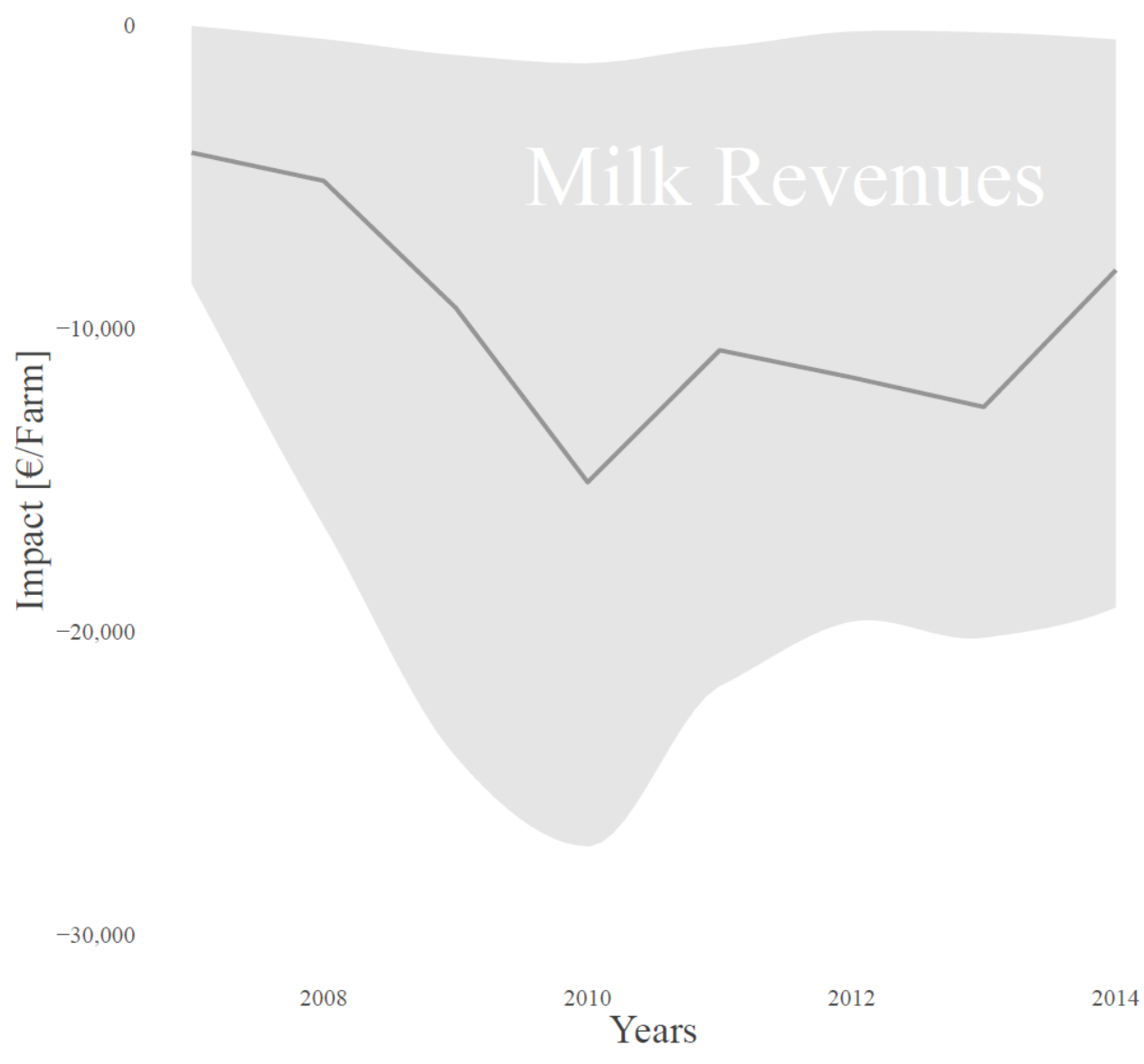

Note that i) the impact of THI load 75 on milk revenues displayed here is based on the estimated relationship between the respective variables and the historical THI exposure, ii) shaded areas indicate minimum and maximum impacts and ii) the solid line indicates the average effect of THI on milk revenues. 
Figure 3: Impact of inputs on expected revenues (absolute effects) and semi-variance (marginal effects) of milk production and animal sales

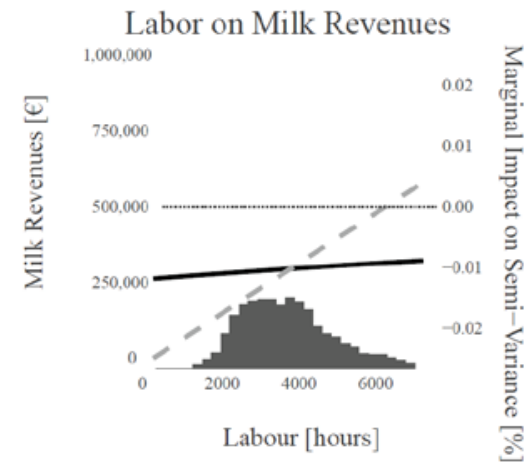

Labor on Animal Sales

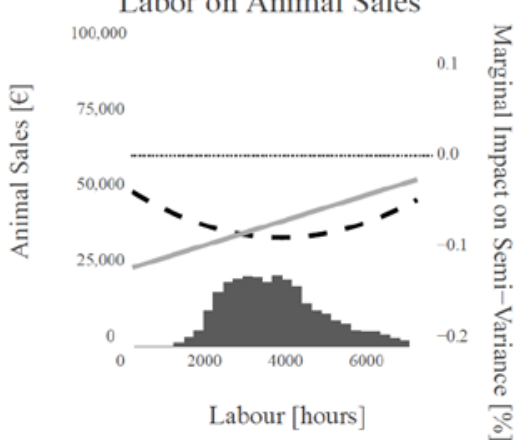

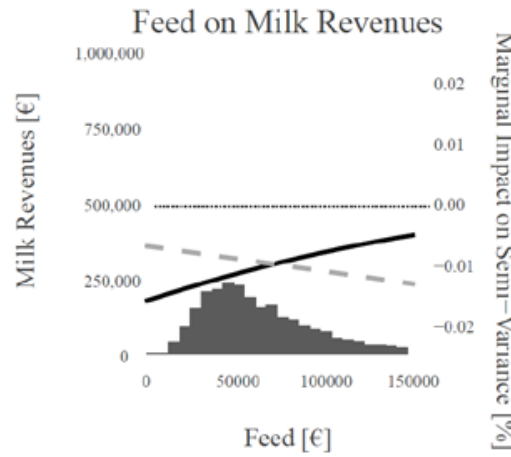

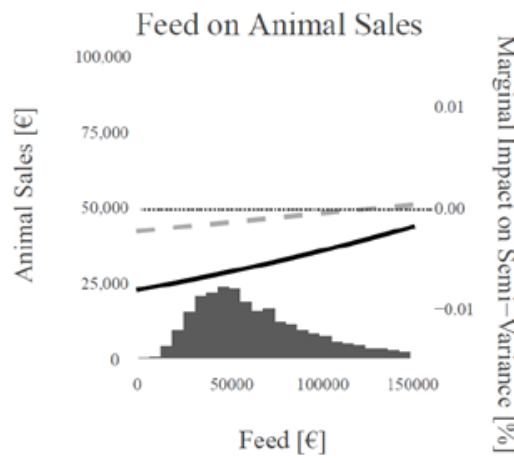

Number of Cattle on Milk Revenues

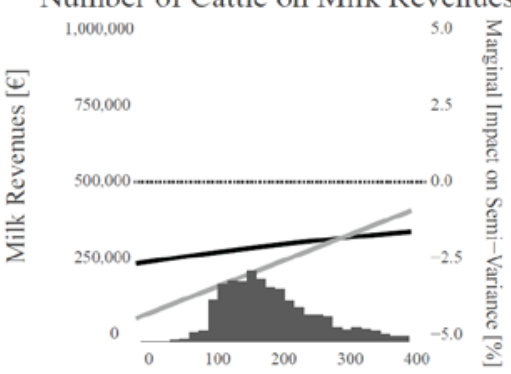

Number of Cattle

Number of Cattle on Animal Sales

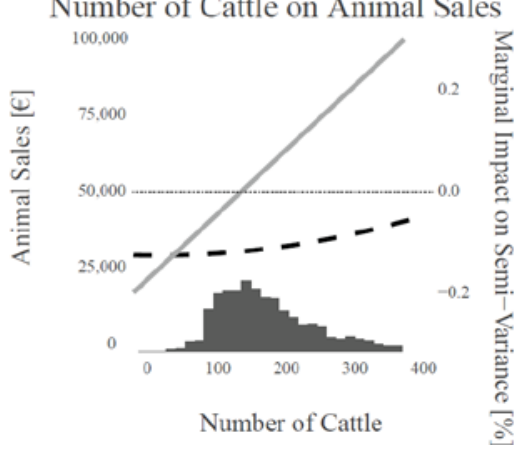

Note that i) black lines represent effects on expected revenues and gray lines represent effects on semi-variances and insignificant effects are displayed as dashed lines, ii) histograms solely refer to the respective input and not to the ordinate axis, iii) displayed input quantity ranges are based on the average value \pm the interquartile range multiplied by 1.5 (boxplot whiskers) and iv) values of all other variables are held constant at the average 


\section{Appendix}

Table A1. Correlations of inputs and outputs

\begin{tabular}{|c|c|c|c|c|c|c|c|c|c|c|c|c|c|}
\hline & 1 & 2 & 3 & 4 & 5 & 6 & 7 & 8 & 9 & 10 & 11 & 12 & 13 \\
\hline \multicolumn{14}{|l|}{1} \\
\hline 2 & 0.781 & & & & & & & & & & & & \\
\hline 3 & 0.518 & 0.408 & & & & & & & & & & & \\
\hline 4 & 0.865 & 0.719 & 0.540 & & & & & & & & & & \\
\hline 5 & 0.930 & 0.770 & 0.450 & 0.816 & & & & & & & & & \\
\hline 6 & 0.825 & 0.715 & 0.625 & 0.807 & 0.805 & & & & & & & & \\
\hline 7 & 0.910 & 0.755 & 0.488 & 0.804 & 0.887 & 0.790 & & & & & & & \\
\hline 8 & 0.069 & 0.049 & 0.042 & 0.046 & 0.094 & 0.116 & 0.068 & & & & & & \\
\hline 9 & -0.052 & -0.109 & -0.003 & -0.070 & -0.027 & -0.019 & -0.039 & 0.140 & & & & & \\
\hline 10 & -0.011 & -0.009 & -0.123 & -0.034 & 0.019 & -0.022 & -0.015 & 0.105 & 0.074 & & & & \\
\hline 11 & 0.095 & 0.148 & -0.005 & 0.103 & 0.166 & 0.154 & 0.184 & 0.092 & 0.009 & 0.045 & & & \\
\hline 12 & 0.936 & 0.772 & 0.532 & 0.875 & 0.892 & 0.843 & 0.881 & 0.070 & -0.043 & -0.006 & 0.159 & & \\
\hline 13 & -0.211 & -0.191 & 0.131 & -0.160 & -0.250 & -0.086 & -0.216 & 0.044 & 0.078 & -0.061 & -0.143 & -0.199 & \\
\hline 14 & 0.109 & 0.165 & -0.060 & 0.090 & 0.196 & 0.087 & 0.216 & 0.004 & 0.028 & 0.077 & 0.115 & 0.105 & -0.254 \\
\hline
\end{tabular}

Notes: Variable numbers as defined in Table 1

Table A2. First stage regression results of 2SLS mean functions

\begin{tabular}{|c|c|c|c|}
\hline & Animal losses & Dead births & $\begin{array}{c}\text { Somatic cell } \\
\text { count }\end{array}$ \\
\hline \multicolumn{4}{|l|}{ Independent variables } \\
\hline \multicolumn{4}{|l|}{ Exogeneous regressors } \\
\hline Land & $\begin{array}{l}-0.022 \\
(0.015)\end{array}$ & $\begin{array}{l}-0.032 * \\
(0.019)\end{array}$ & $\begin{array}{l}-0.347 \\
(0.254)\end{array}$ \\
\hline Labor & $\begin{array}{c}-0.001^{* *} \\
(0.000)\end{array}$ & $\begin{array}{c}-0.001^{* *} \\
(0.000)\end{array}$ & $\begin{array}{c}-0.008^{* *} \\
(0.004)\end{array}$ \\
\hline Feed & $\begin{array}{l}-0.00 *^{*} \\
(0.000)\end{array}$ & $\begin{array}{l}-0.000 \\
(0.000)\end{array}$ & $\begin{array}{l}-0.000 \\
(0.000)\end{array}$ \\
\hline No. of cattle & $\begin{array}{l}-0.002 \\
(0.006)\end{array}$ & $\begin{array}{l}0.014^{*} \\
(0.008)\end{array}$ & $\begin{array}{l}-0.007 \\
(0.085)\end{array}$ \\
\hline Costs & $\begin{array}{c}0.000 \\
(0.000)\end{array}$ & $\begin{array}{l}-0.000 \\
(0.000)\end{array}$ & $\begin{array}{c}0.000^{* * *} \\
(0.000)\end{array}$ \\
\hline Land*Land & $\begin{array}{c}0.000 \\
(0.000)\end{array}$ & $\begin{array}{c}0.000 \\
(0.000)\end{array}$ & $\begin{array}{l}0.002^{*} \\
(0.001)\end{array}$ \\
\hline Labor*Labor & $\begin{array}{c}0.000 \\
(0.000)\end{array}$ & $\begin{array}{c}0.000 \\
(0.000)\end{array}$ & $\begin{array}{l}-0.000 \\
(0.000)\end{array}$ \\
\hline Feed*Feed & $\begin{array}{l}-0.000 \\
(0.000)\end{array}$ & $\begin{array}{c}0.000 \\
(0.000)\end{array}$ & $\begin{array}{l}-0.000^{*} \\
(0.000)\end{array}$ \\
\hline $\begin{array}{l}\text { No. of Cattle* No. of } \\
\text { Cattle }\end{array}$ & $\begin{array}{c}0.000 \\
(0.000)\end{array}$ & $\begin{array}{l}-0.000 \\
(0.000)\end{array}$ & $\begin{array}{l}0.000 \\
(0.000)\end{array}$ \\
\hline Costs*Costs & $\begin{array}{l}-0.000 \\
(0.000)\end{array}$ & $\begin{array}{l}0.000 * * \\
(0.000)\end{array}$ & $\begin{array}{l}-0.000^{*} \\
(0.000)\end{array}$ \\
\hline
\end{tabular}




\begin{tabular}{|c|c|c|c|}
\hline Land*Labor & $\begin{array}{c}0.000 * * * \\
(0.000)\end{array}$ & $\begin{array}{l}0.000 * \\
(0.000)\end{array}$ & $\begin{array}{c}0.000 \\
(0.000)\end{array}$ \\
\hline Land*Feed & $\begin{array}{c}0.000 \\
(0.000)\end{array}$ & $\begin{array}{l}-0.000 \\
(0.000)\end{array}$ & $\begin{array}{l}-0.000 \\
(0.000)\end{array}$ \\
\hline Land $*$ No. of Cattle & $\begin{array}{l}-0.000 \\
(0.000)\end{array}$ & $\begin{array}{l}-0.000 \\
(0.000)\end{array}$ & $\begin{array}{l}-0.000 \\
(0.001)\end{array}$ \\
\hline Land*Costs & $\begin{array}{l}-0.000 \\
(0.000)\end{array}$ & $\begin{array}{c}0.000 \\
(0.000)\end{array}$ & $\begin{array}{c}0.000 \\
(0.000)\end{array}$ \\
\hline Labor*Feed & $\begin{array}{l}-0.000 \\
(0.000)\end{array}$ & $\begin{array}{c}0.000 \\
(0.000)\end{array}$ & $\begin{array}{c}0.000 \\
(0.000)\end{array}$ \\
\hline Labor* No. of Cattle & $\begin{array}{l}-0.000 \\
(0.000)\end{array}$ & $\begin{array}{l}-0.000 \\
(0.000)\end{array}$ & $\begin{array}{c}0.000 \\
(0.000)\end{array}$ \\
\hline Labor*Costs & $\begin{array}{l}-0.000 \\
(0.000)\end{array}$ & $\begin{array}{l}-0.000 \\
(0.000)\end{array}$ & $\begin{array}{l}-0.000 \\
(0.000)\end{array}$ \\
\hline Feed* No. of Cattle & $\begin{array}{c}0.000 \\
(0.000)\end{array}$ & $\begin{array}{c}0.000 \\
(0.000)\end{array}$ & $\begin{array}{c}0.000 \\
(0.000)\end{array}$ \\
\hline Feed ${ }^{*}$ Costs & $\begin{array}{c}0.000 \\
(0.000)\end{array}$ & $\begin{array}{l}-0.000 * \\
(0.000)\end{array}$ & $\begin{array}{c}0.000 * * \\
(0.000)\end{array}$ \\
\hline No. of Cattle*Costs & $\begin{array}{l}-0.000 \\
(0.000)\end{array}$ & $\begin{array}{c}0.000 \\
(0.000)\end{array}$ & $\begin{array}{l}-0.000 \\
(0.000)\end{array}$ \\
\hline THI Load 75 & $\begin{array}{l}-0.006 \\
(0.004)\end{array}$ & $\begin{array}{c}0.008 \\
(0.005)\end{array}$ & $\begin{array}{l}-0.036 \\
(0.052)\end{array}$ \\
\hline Milk quota & $\begin{array}{c}0.000 * * * \\
(0.000)\end{array}$ & $\begin{array}{c}0.000 \\
(0.000)\end{array}$ & $\begin{array}{l}-0.000 \\
(0.000)\end{array}$ \\
\hline Instruments & & & \\
\hline First calving age t-1 & $\begin{array}{c}0.066 \\
(0.045)\end{array}$ & $\begin{array}{c}-0.104 \\
(0.065)\end{array}$ & $\begin{array}{l}-0.163 \\
(0.555)\end{array}$ \\
\hline Somatic cell count t-1 & $\begin{array}{l}0.004^{* *} \\
(0.002)\end{array}$ & $\begin{array}{c}0.003 \\
(0.002)\end{array}$ & $\begin{array}{c}0.222 * * * \\
(0.027)\end{array}$ \\
\hline Animal losses t-1 & $\begin{array}{c}-0.096 * * * \\
(0.027)\end{array}$ & $\begin{array}{l}-0.037 \\
(0.033)\end{array}$ & $\begin{array}{c}0.591^{* *} \\
(0.293)\end{array}$ \\
\hline Dead births t-1 & $\begin{array}{c}0.003 \\
(0.016)\end{array}$ & $\begin{array}{c}0.091^{* * *} \\
(0.032)\end{array}$ & $\begin{array}{c}0.114 \\
(0.209)\end{array}$ \\
\hline $\begin{array}{l}\text { Veterinary expenditure } \\
\text { t-1 }\end{array}$ & $\begin{array}{l}-0.003 \\
(0.002)\end{array}$ & $\begin{array}{c}-0.003 \\
(0.003)\end{array}$ & $\begin{array}{l}-0.034 \\
(0.031)\end{array}$ \\
\hline $\mathrm{F}^{\mathrm{a}}$ & 12.81 & 24.59 & 20.70 \\
\hline$p$-value & 0.000 & 0.000 & 0.000 \\
\hline $\operatorname{adj} . R^{2}$ & 0.355 & 0.373 & 0.629 \\
\hline $\mathrm{n}$ & 2,630 & 2,630 & 2,630 \\
\hline
\end{tabular}

Notes: Dependent variable is somatic cell count. Standard errors in parentheses.

$* * *, * *, *$ indicates significance at the 10,5 , and $1 \%$ - level, respectively.

a refers to the general F-test of the first-stage regression 
Table A3. Input elasticity estimates and regression coefficients for THI, milk quota and animal health factors with interaction terms

\begin{tabular}{|c|c|c|c|c|c|}
\hline \multirow{2}{*}{$\begin{array}{l}\text { Inputs/control } \\
\text { variables }\end{array}$} & \multicolumn{2}{|l|}{ Milk } & \multicolumn{2}{|l|}{ Animal sales } & \multirow[b]{2}{*}{ Semi-covariance } \\
\hline & Mean & Semi-variance & Mean & Semi-variance & \\
\hline \multicolumn{6}{|l|}{ Elasticities } \\
\hline \multirow[t]{2}{*}{ Land } & -0.099 & $0.773 * *$ & -0.097 & -0.37 & $-0.542 *$ \\
\hline & $(0.037)$ & $(0.331)$ & (0.129) & $(0.267)$ & $(0.291)$ \\
\hline \multirow[t]{2}{*}{ Labor } & $0.113^{* * *}$ & 0.519 & 0.029 & $-1.011^{*}$ & -0.615 \\
\hline & (0.029) & $(0.533)$ & $(0.093)$ & $(0.569)$ & $(0.475)$ \\
\hline \multirow[t]{2}{*}{ Feed } & $0.33 * * *$ & 0.871 & 0.338 & 0.283 & $0.958 *$ \\
\hline & $(0.033)$ & (0.609) & $(0.084)$ & $(0.673)$ & $(0.563)$ \\
\hline \multirow[t]{2}{*}{ No. of cattle } & $0.161 * * *$ & $-2.838 * *$ & 0.219 & $1.126^{* *}$ & -0.872 \\
\hline & $(0.045)$ & $(1.393)$ & $(0.153)$ & 0.509 & $(0.661)$ \\
\hline \multirow[t]{2}{*}{ Costs } & $0.119 * * *$ & 0.472 & -0.092 & 0.127 & 0.156 \\
\hline & $(0.023)$ & $(0.576)$ & $(0.071)$ & $(0.879)$ & $(0.460)$ \\
\hline \multicolumn{6}{|l|}{ Regression coefficients } \\
\hline \multirow[t]{2}{*}{ Somatic cell count } & $-228.15^{* *}$ & -5921950 & 4.181 & -157257.3 & -418419.6 \\
\hline & (98.711) & $(2215541)^{* * *}$ & (31.599) & $(95083.88)^{*}$ & $(350538.2)$ \\
\hline \multirow[t]{2}{*}{ Animal losses } & $5821.383^{* *}$ & $3.29 \mathrm{e} 8 * * *$ & $1772.818^{* *}$ & $1.18 \mathrm{e} 7 * * *$ & $5.94 \mathrm{e} 7 * * *$ \\
\hline & $(2494.783)$ & $(3.98 \mathrm{e} 7)$ & $(760.881)$ & $(1828590)$ & (7811891) \\
\hline \multirow[t]{2}{*}{ Dead births } & 250.048 & $6.08 \mathrm{e} 7 * * *$ & -433.959 & -985138 & 5538159 \\
\hline & $(1893.67)$ & $(2.66 \mathrm{e})$ & $(563.841)$ & $(1030456)$ & (4449029) \\
\hline \multirow[t]{2}{*}{ THI Load 75} & $-167.361^{* * *}$ & 2836334 & 10.251 & $388200.6 *$ & 685842.3 \\
\hline & $(51.782)$ & $(5547605)$ & $(16.577)$ & $(210491.4)$ & (775890.9) \\
\hline \multirow[t]{2}{*}{ Milk quota } & $0.103^{* *}$ & 1553.617 & 0.001 & 83.804 & 234.587 \\
\hline & $(0.027)$ & (1443.749) & $(0.005)$ & $(63.736)$ & $(193.063)$ \\
\hline \multirow[t]{2}{*}{ Land*Land } & 0.150 & -243703.000 & -0.104 & -4657.853 & $-30966.780 *$ \\
\hline & $(1.051)$ & (155582.900) & $(0.308)$ & (4029.839) & $(16189.180)$ \\
\hline \multirow[t]{2}{*}{ Labor*Labor } & -0.000 & 125.038 & $0.001 * *$ & $14.628 * *$ & $42.955^{*}$ \\
\hline & $(0.001)$ & $(139.790)$ & $(0.000)$ & $(6.327)$ & $(23.783)$ \\
\hline \multirow[t]{2}{*}{ Feed*Feed } & $-0.000 *$ & $-1.238 * *$ & 0.000 & 0.018 & $-0.195 * * *$ \\
\hline & $(0.000)$ & $(0.532)$ & $(0.000)$ & $(0.017)$ & $(0.058)$ \\
\hline No. of Cattle* No. of & -0.167 & $257953.200 * *$ & 0.086 & 1334.746 & $33216.260 * * *$ \\
\hline Cattle & $(0.567)$ & $(117803.800)$ & $(0.154)$ & $(1914.600)$ & $(11619.460)$ \\
\hline \multirow[t]{2}{*}{ Costs*Costs } & 0.000 & $-0.438 *$ & $0.000 * * *$ & $0.047^{* *}$ & -0.012 \\
\hline & $(0.000)$ & $(0.266)$ & $(0.000)$ & $(0.023)$ & $(0.032)$ \\
\hline \multirow[t]{2}{*}{ Land*Labor } & -0.069 & $-17523.210 * *$ & $-0.050 * *$ & -292.844 & $-2813.138^{* *}$ \\
\hline & $(0.087)$ & (8905.824) & $(0.021)$ & $(305.788)$ & $(1257.922)$ \\
\hline \multirow[t]{2}{*}{ Land*Feed } & -0.001 & $575.677^{*}$ & $-0.001^{*}$ & -20.755 & 65.654 \\
\hline & $(0.002)$ & (297.328) & $(0.001)$ & (16.110) & (41.961) \\
\hline \multirow[t]{2}{*}{ Land $*$ No. of Cattle } & $3.181 * *$ & $674292.900 * * *$ & $1.523 * * *$ & 8311.294 & $49069.110^{* *}$ \\
\hline & $(1.586)$ & $(255317.200)$ & $(0.406)$ & (5500.180) & (22297.740) \\
\hline
\end{tabular}




\begin{tabular}{|c|c|c|c|c|c|}
\hline Land*Costs & $\begin{array}{l}-0.003 \\
(0.002)\end{array}$ & $\begin{array}{l}-838.172 * * \\
(374.772)\end{array}$ & $\begin{array}{l}-0.000 \\
(0.001)\end{array}$ & $\begin{array}{l}12.964 \\
(14.105)\end{array}$ & $\begin{array}{l}-33.239 \\
(42.485)\end{array}$ \\
\hline Labor*Feed & $\begin{array}{l}0.000 * * * \\
(0.000)\end{array}$ & $\begin{array}{l}-5.076 \\
(9.673)\end{array}$ & $\begin{array}{l}0.000 \\
(0.000)\end{array}$ & $\begin{array}{l}0.980 * \\
(0.589)\end{array}$ & $\begin{array}{l}4.108 * * * \\
(1.532)\end{array}$ \\
\hline Labor* No. of Cattle & $\begin{array}{l}-0.058 \\
(0.049)\end{array}$ & $\begin{array}{l}-6003.888 \\
(4877.211)\end{array}$ & $\begin{array}{l}-0.022 \\
(0.015)\end{array}$ & $\begin{array}{l}-213.063 \\
(172.843)\end{array}$ & $\begin{array}{l}-875.302 \\
(724.999)\end{array}$ \\
\hline Labor*Costs & $\begin{array}{l}-0.000 \\
(0.000)\end{array}$ & $\begin{array}{l}6.221 \\
(10.394)\end{array}$ & $\begin{array}{l}-0.000 \\
(0.000)\end{array}$ & $\begin{array}{l}-1.319 * \\
(0.677)\end{array}$ & $\begin{array}{l}-2.714 \\
(1.762)\end{array}$ \\
\hline Feed* No. of Cattle & $\begin{array}{l}-0.001 \\
(0.002)\end{array}$ & $\begin{array}{l}137686 \\
(282.787)\end{array}$ & $\begin{array}{l}-0.000 \\
(0.000)\end{array}$ & $\begin{array}{l}-7.933 \\
(8.644)\end{array}$ & $\begin{array}{l}-23.071 \\
(38.122)\end{array}$ \\
\hline Feed*Costs & $\begin{array}{l}-0.000 \\
(0.000)\end{array}$ & $\begin{array}{l}1.771 * * \\
(0.856)\end{array}$ & $\begin{array}{l}-0.000 \\
(0.000)\end{array}$ & $\begin{array}{l}-0.059 * \\
(0.034)\end{array}$ & $\begin{array}{l}0.205 * * \\
(0.093)\end{array}$ \\
\hline No. of Cattle*Costs & $\begin{array}{l}0.004 * * * \\
(0.001)\end{array}$ & $\begin{array}{l}-439.918^{*} \\
(247.164)\end{array}$ & $\begin{array}{l}-0.001 \\
(0.000)\end{array}$ & $\begin{array}{l}9.567 \\
(7.468)\end{array}$ & $\begin{array}{l}-37.854 \\
(25.925)\end{array}$ \\
\hline $\mathrm{F}$ & & 25.340 & & 5.220 & 9.340 \\
\hline$p$-value & & 0.000 & & 0.000 & 0.000 \\
\hline Wald $\chi 2$ & 80281.48 & & 8041.70 & & \\
\hline$p$-value & 0.000 & & 0.000 & & \\
\hline Sargan $\chi 2$ & 1.473 & & 0.064 & & \\
\hline$p$-value & 0.479 & & 0.969 & & \\
\hline$n$ & 2,630 & 1,706 & 2,630 & 1,573 & 1,001 \\
\hline First stage statistics & & & & & \\
\hline Min. eigenvalue stat. & 4.607 & & 4.607 & & \\
\hline Critical value & 4.300 & & 4.300 & & \\
\hline
\end{tabular}

Notes: Values for inputs (land, labor, feed, no. of cattle, and costs) are output elasticities w.r.t. those inputs; values for somatic cell count, calving age, THI load 75, and milk quota are regression coefficients.

Heteroskedasticity robust standard errors in parentheses.

$*, * *, * * *$ indicates significance at the 10,5 , and $1 \%$ - level, respectively. 
Figure A1. Location of farms.

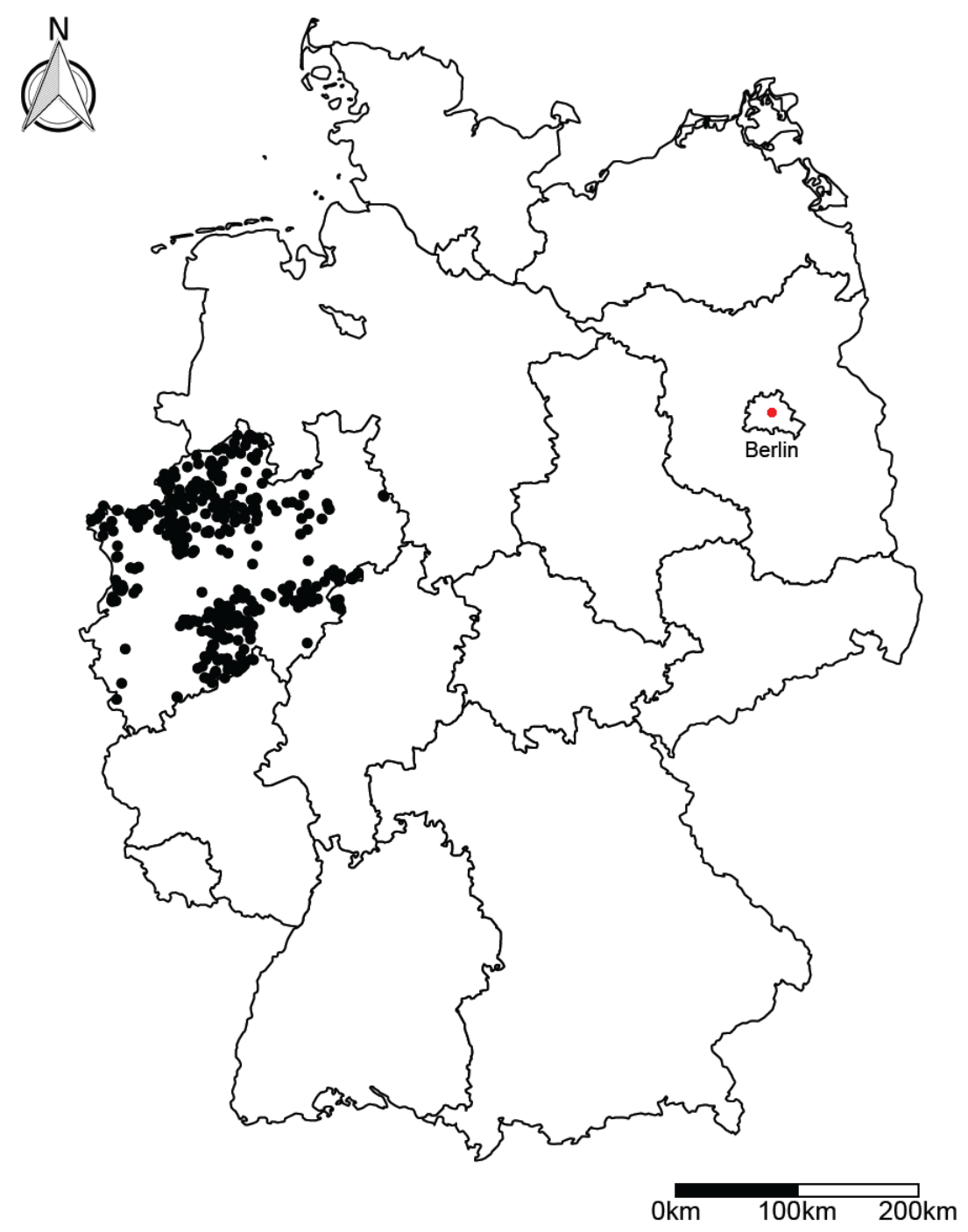


Figure A2. THI load for the years 2007-2014.

THI Load 75
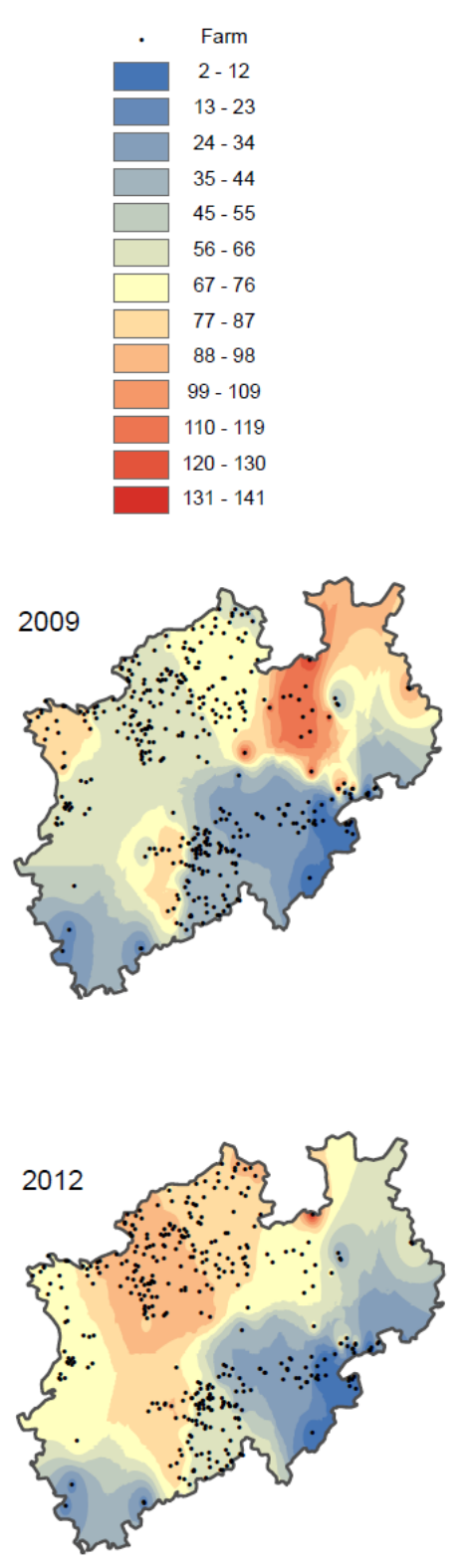
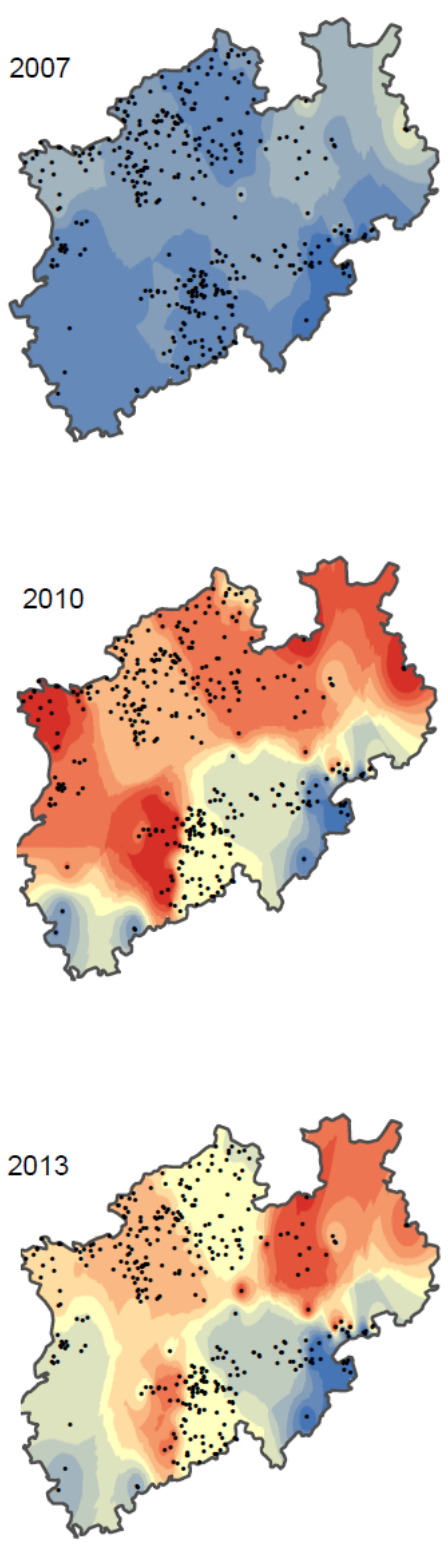
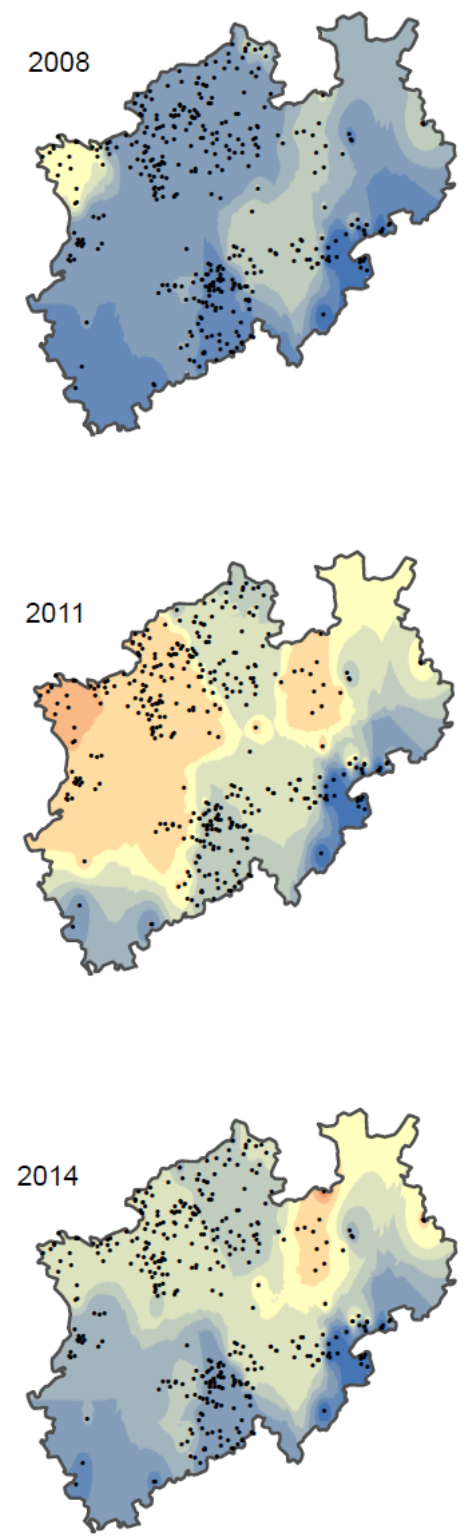
Figure A3: Impact of inputs on expected revenues (absolute effects) and semi-variance (marginal effects) of milk production and animal sales
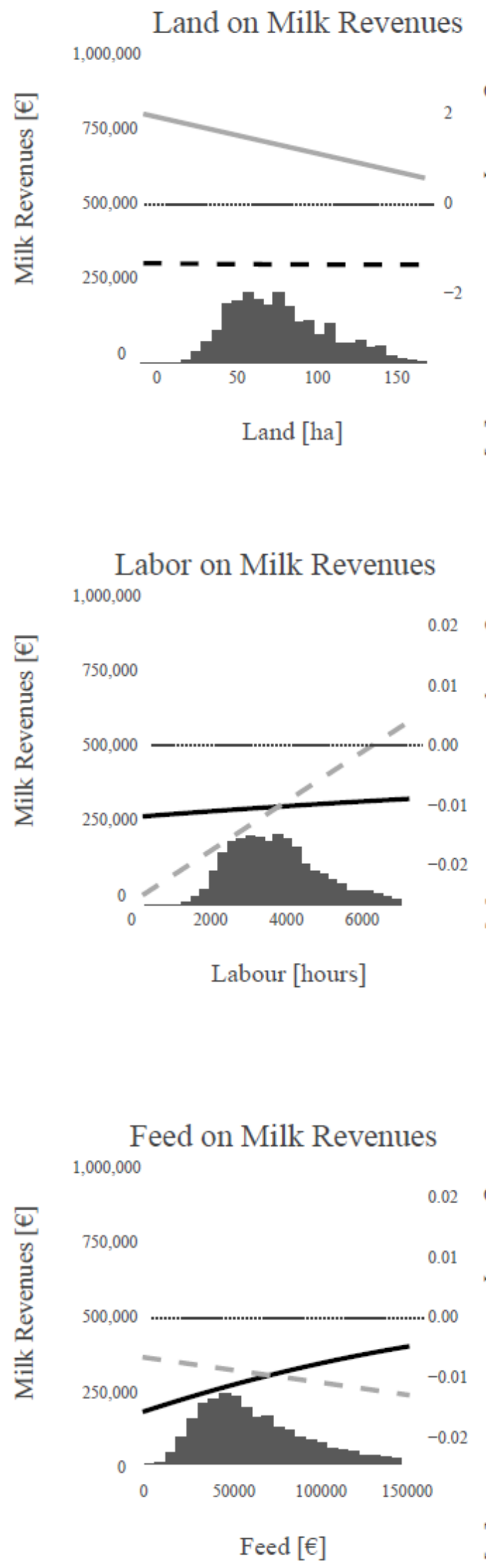
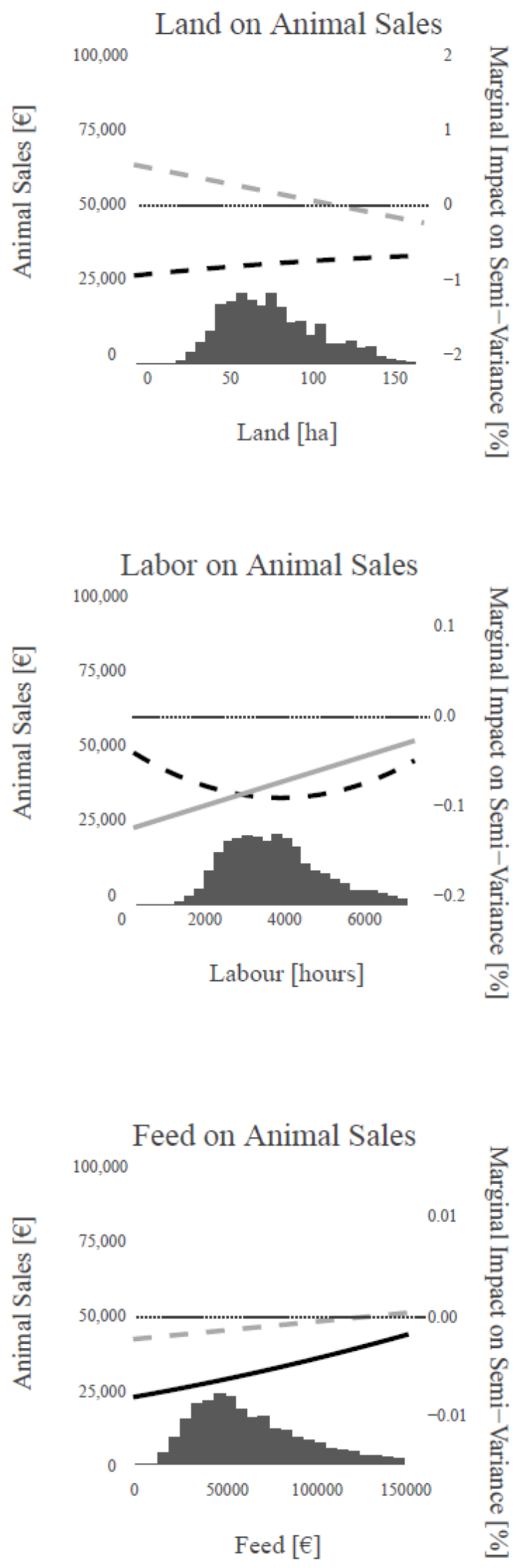

Figure A3 cont. 
Number of Cattle on Milk Revenues

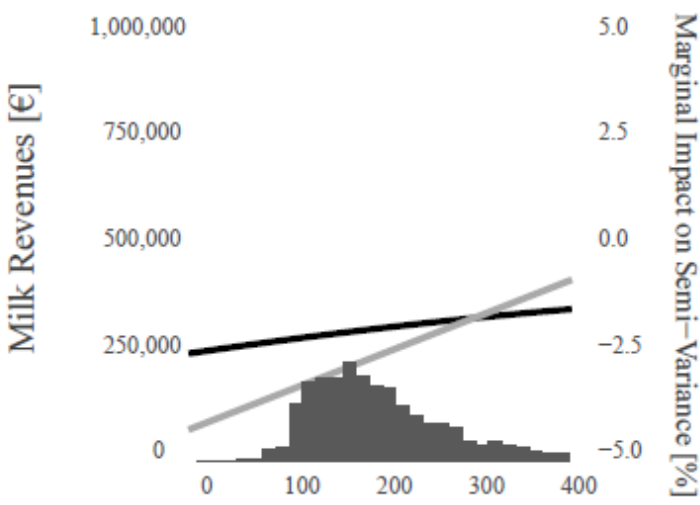

Number of Cattle

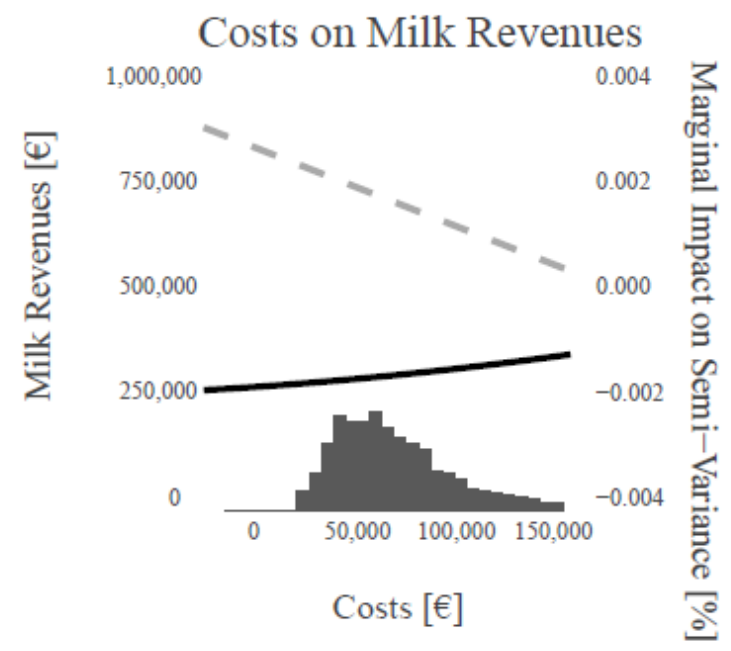

Number of Cattle on Animal Sales

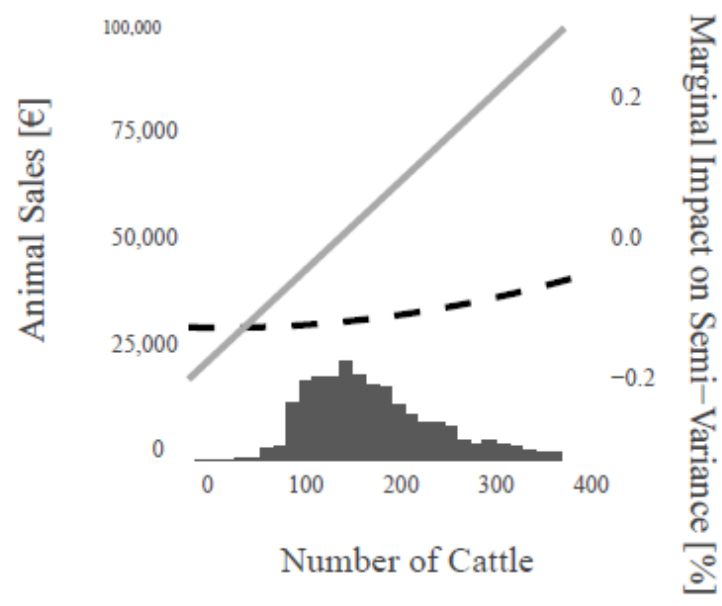

Costs on Animal Sales

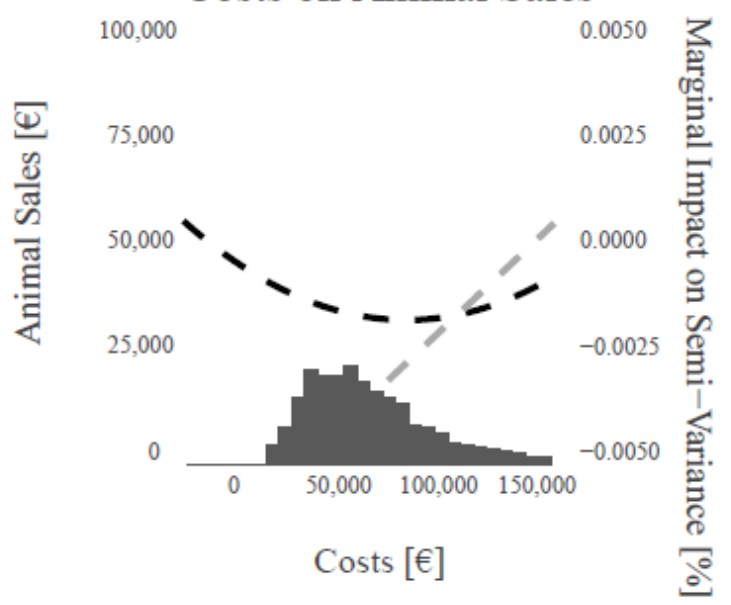

